\title{
Evolution and Controls of Large Glacial Lakes in the Nepal Himalaya
}

\author{
Umesh K. Haritashya ${ }^{1, *(1)}$, Jeffrey S. Kargel ${ }^{2}$, Dan H. Shugar ${ }^{3}$ (i) , Gregory J. Leonard ${ }^{4}$, \\ Katherine Strattman ${ }^{1}$, C. Scott Watson ${ }^{5}$, David Shean ${ }^{6}{ }^{(1)}$, Stephan Harrison ${ }^{7}$, \\ Kyle T. Mandli 8 (i) and Dhananjay Regmi ${ }^{9}$ \\ 1 Department of Geology, University of Dayton, Dayton, OH 45458, USA; strattmank1@udayton.edu \\ 2 Planetary Science Institute, Tucson, AZ 85719, USA; jeffreyskargel@hotmail.com \\ 3 Water, Sediment, Hazards, and Earth-Surface Dynamics (waterSHED) Laboratory, \\ University of Washington Tacoma, Tacoma, WA 98402, USA; dshugar@uw.edu \\ 4 Department of Planetary Sciences, University of Arizona, Tucson, AZ 85721, USA; \\ gleonard@email.arizona.edu \\ 5 Department of Hydrology and Atmospheric Sciences, University of Arizona, Tucson, AZ 85721, USA; \\ cswatson@email.arizona.edu \\ 6 Department of Civil and Environmental Engineering, University of Washington, Seattle, WA 98195, USA; \\ dshean@uw.edu \\ 7 Department of Geography, Exeter University, Exeter TR10 9FE, UK; stephan.harrison@exeter.ac.uk \\ 8 Department of Applied Physics and Applied Mathematics, Columbia University, New York, NY 10027, USA; \\ kyle.mandli@columbia.edu \\ $9 \quad$ Himalayan Research Centre, Kathmandu 44600, Nepal; dj.regmi@gmail.com \\ * Correspondence: uharitashya1@udayton.edu; Tel.: +1-937-229-2939
}

Received: 9 April 2018; Accepted: 17 May 2018; Published: 21 May 2018

check for updates

\begin{abstract}
Glacier recession driven by climate change produces glacial lakes, some of which are hazardous. Our study assesses the evolution of three of the most hazardous moraine-dammed proglacial lakes in the Nepal Himalaya-Imja, Lower Barun, and Thulagi. Imja Lake (up to $150 \mathrm{~m}$ deep; $78.4 \times 10^{6} \mathrm{~m}^{3}$ volume; surveyed in October 2014) and Lower Barun Lake (205 m maximum observed depth; $112.3 \times 10^{6} \mathrm{~m}^{3}$ volume; surveyed in October 2015) are much deeper than previously measured, and their readily drainable volumes are slowly growing. Their surface areas have been increasing at an accelerating pace from a few small supraglacial lakes in the 1950s/1960s to $1.33 \mathrm{~km}^{2}$ and $1.79 \mathrm{~km}^{2}$ in 2017, respectively. In contrast, the surface area $\left(0.89 \mathrm{~km}^{2}\right)$ and volume of Thulagi lake (76 m maximum observed depth; $36.1 \times 10^{6} \mathrm{~m}^{3}$; surveyed in October 2017) has remained almost stable for about two decades. Analyses of changes in the moraine dams of the three lakes using digital elevation models (DEMs) quantifies the degradation of the dams due to the melting of their ice cores and hence their natural lowering rates as well as the potential for glacial lake outburst floods (GLOFs). We examined the likely future evolution of lake growth and hazard processes associated with lake instability, which suggests faster growth and increased hazard potential at Lower Barun lake.
\end{abstract}

Keywords: GLOF; glacial lake; Nepal; Himalaya; proglacial lake; moraine-dammed; glacier; remote sensing; High Mountain Asia (HMA)

\section{Introduction}

Glaciers worldwide are highly sensitive to climate change, though they respond on a range of timescales (typically a few decades to a century or more for temperate alpine glaciers) [1,2]. As a result, they are excellent, albeit complex, indicators of climate change [3-5]. One of the biggest controversies of the last decade over the false claim of impending disappearance of Himalayan glaciers by the year 
2035 [6] based on errant information [7-9] resulted in an intense and continuing research focus that has greatly improved our knowledge of Himalayan glaciers [10-14]. In the past decade, the glaciological community has learned, for example, that glacier mass loss rates in High Mountain Asia (HMA) are comparable with the global average mass loss rates [15], and that mass loss, thinning, length, and area retreat rates of glaciers in the region are heterogeneous [11,13,14,16,17]. Also, documented better than ever before, is the spatiotemporal frequency and magnitude of changes in Himalayan glacial lakes. Climate model projections driven by high emissions scenarios suggest that HMA will lose as much as $65 \%$ of its ice mass this century [1], which could result in the formation of thousands of new glacial lakes.

Recent studies [18-21] have shown that enhanced meltwater production and glacier retreat coupled with increased area to hold meltwater in newly exposed glacial over-deepenings leads to moraine-dammed proglacial lakes. In the Nepal Himalaya, the majority of present-day large moraine-dammed lakes did not exist before the 1950s [22]. Many of these lakes started forming in the mid-1950s to 1960s as small supraglacial lakes, which coalesced and started growing rapidly in the 1970s [23-25]. According to one estimate, there are over 1466 glacial lakes in the Nepal Himalaya alone [26] and it has been suggested that most of these formed in response to warming temperatures during the second half of the 20th century $[26,27]$. However, one recent study assigns a longer sequence of response times, such that lakes growing between the 1950s and 2010s may be long-delayed responses to climatic shifts that occurred over the previous one to two centuries, including but not necessarily dominated by the anthropogenic warming of recent decades [28].

Out of the known 1466 glacial lakes, 21 have been identified as posing exceptional risk of glacial lake outburst floods (GLOFs), including Imja, Lower Barun, and Thulagi [26]. A more recent study, however, classified both risks and hazards for these lakes and determined Lower Barun as a high hazard and high risk, Thulagi (locally known as Dona Lake) as a moderate hazard but high risk, and Imja (locally known as Imja Tsho) as both a moderate hazard and risk [29,30] partly due to a recent lake-lowering project $[29,31]$. However, the study pointed out that the continued expansion of Imja Lake could increase its hazard profile due to the high susceptibility of avalanches entering the lake. The approach to classifying GLOF risk (exceptional, very high, high, or moderate) is different in these studies. Overall, the variability in risks and the rate of lake growth, both in Nepal and the broader HMA region, depends on a number of factors including glacier microclimate, topography, glacier dynamics, glacier debris cover, unstable mass around a lake, proximity to downstream infrastructure, potential flood volume, and peak discharge [32]. Specifically, the intrinsic hazards, risk exposure, and vulnerabilities from glacial lakes are great in the high relief areas around the Mount Everest and Makalu massifs in Nepal, which contain numerous large lakes and observe frequent slope failure and flash floods associated with monsoon rain.

Glacial lakes with moraine dams are metastable. Those with ice cores are subject to melting, gravitational collapse, or buoyant flotation; even if the dams hold up, mass movements-debris flows, rock slope failures, and avalanches-into the lakes can produce massive overtopping waves [33,34]. As a result, there is a potential for many of these lakes to produce sudden GLOFs, which can devastate downstream areas causing possible loss of life and damage to local infrastructure. Although not all glacial lakes are hazardous, some will inevitably produce damaging GLOFs given the glacial lake system dynamics, topographic setting, and downstream populations and infrastructure. While glacial lakes have been controlled by engineering to reduce their GLOF potential, most of these are in Peru; in HMA, similar efforts are limited [31,35-37].

GLOF events from glacial lakes are a worldwide phenomenon [34,38-50]. Although there have been suggestions that the GLOF frequency in the Himalayan region has increased in recent decades [5], a statistical assessment of moraine-breach GLOFs shows that the number of GLOFs have declined there and around the world following an increase in the mid-20th century [28]. The GLOF rate trends are attributed to glaciological and limnological response times following climatic fluctuations, including the end of the Little Ice Age and more recent warming. Reference [51] examined all types of 
GLOFs, including ice-dammed and moraine-dammed lake outbursts, and identified a similar early 20th-century rise of global GLOFs followed by a stabilization over the past three decades. To date, no systematic account for the long response times between climatic perturbations and lake formation and drainage has been established. This presumably includes timescales needed for the critical thinning, retreat, and change of the glacier surface relief to allow for the pooling of water and lake growth, as well as stochastic periods between triggering events such as landslides or extreme weather [28,52]. While GLOFs occur relatively infrequently, because many glaciers are undergoing the type of thinning and flow stagnation that creates metastable lakes, it is likely that the risk of GLOFs may increase in the future. Nonetheless, they pose a severe flood risk in the high mountains [53], even though the full impact of anthropogenic warming has not yet been reflected in GLOF activity. To understand these risks, we selected three major glacial lakes in Nepal (Imja, Lower Barun, and Thulagi) where we have detailed field and historical records to develop a broad regional understanding of glacial lake evolution. Specifically, we investigated a satellite time-series of the lake area, ice velocity, lake volume growth, moraine and ice elevation changes, and the evaluated hazards resulting from these changes.

\section{Study Area}

Imja (Randolph Glacier Inventory (RGI) ID_RGI60-15.03743; Global Land Ice Measurements from Space (GLIMS) ID-G086958E27924N), Lower Barun (RGI ID-RGI60-15.03366; GLIMS ID_G087008E27832N), and Thulagi lakes (RGI ID—RGI60-15.05140; GLIMS ID—G084537E28518N) are all large glacial lakes fed by temperate glaciers located on the southern flank of the Himalayan range; geographically, they are located south of the Tibetan Plateau where cold-based and polythermal glaciers dominate (Figure 1). Each of these glacial lakes is located adjacent to one of the world's highest massifs: Everest-Lhotse (world's highest), Makalu (5th highest), and Manaslu (8th highest) respectively, and each is dammed by an ice-cored moraine.

\subsection{Imja}

Imja Lake is located in the easternmost part of the Sagarmatha region in Solukhumbu district $\left(27^{\circ} 53^{\prime} 55^{\prime \prime} \mathrm{N}, 86^{\circ} 55^{\prime} 21^{\prime \prime} \mathrm{E} ; 5000 \mathrm{~m}\right.$ a.s.1.), Nepal, about $9 \mathrm{~km}$ south of Mt. Everest, and a few kilometers south of Lhotse Peak, the highest and fourth highest peaks in the world, respectively. Imja lake is bounded to the east by the calving front of Imja/Lhotse Shar glaciers, to the north and south by lateral moraines, and to the west by the ice-cored end moraine. The lake has grown since its inception as an innocuous set of supraglacial lakes in the 1950s [26]. Lhotse Shar, Imja, and Amphulapche glaciers were the original parent glaciers of the Imja Glacier system and Lake. However, Amphulapche Glacier has completely detached, and no longer contributes any ice or water to the lake or to Imja Glacier. Imja Glacier itself has dramatically reduced in size, leaving Lhotse Shar Glacier as the largest source of meltwater contribution into the lake (Figure S1). The area of the entire Imja basin is about $141 \mathrm{~km}^{2}$, and approximately 38\% of the basin is covered by glaciers [54]. Much of the unglacierized portion consists of steep mountain slopes which generate snow avalanches that run out onto the glaciers [29]. Imja Lake's lateral moraine trough acts as a "gutter", trapping debris derived from rockfall, snow avalanches, and fluvial transport [55]. Large, rapid mass movements, however, could potentially overrun or even breach the lateral moraines and enter Imja Lake. It is also an important lake from a hazards perspective because it is situated upstream from a major Everest access route for trekkers and climbers and the villages that have grown to support those activities. Recently, Imja lake's level was lowered to reduce the potential risk of GLOF (discussed in detail in Section 5.6). 


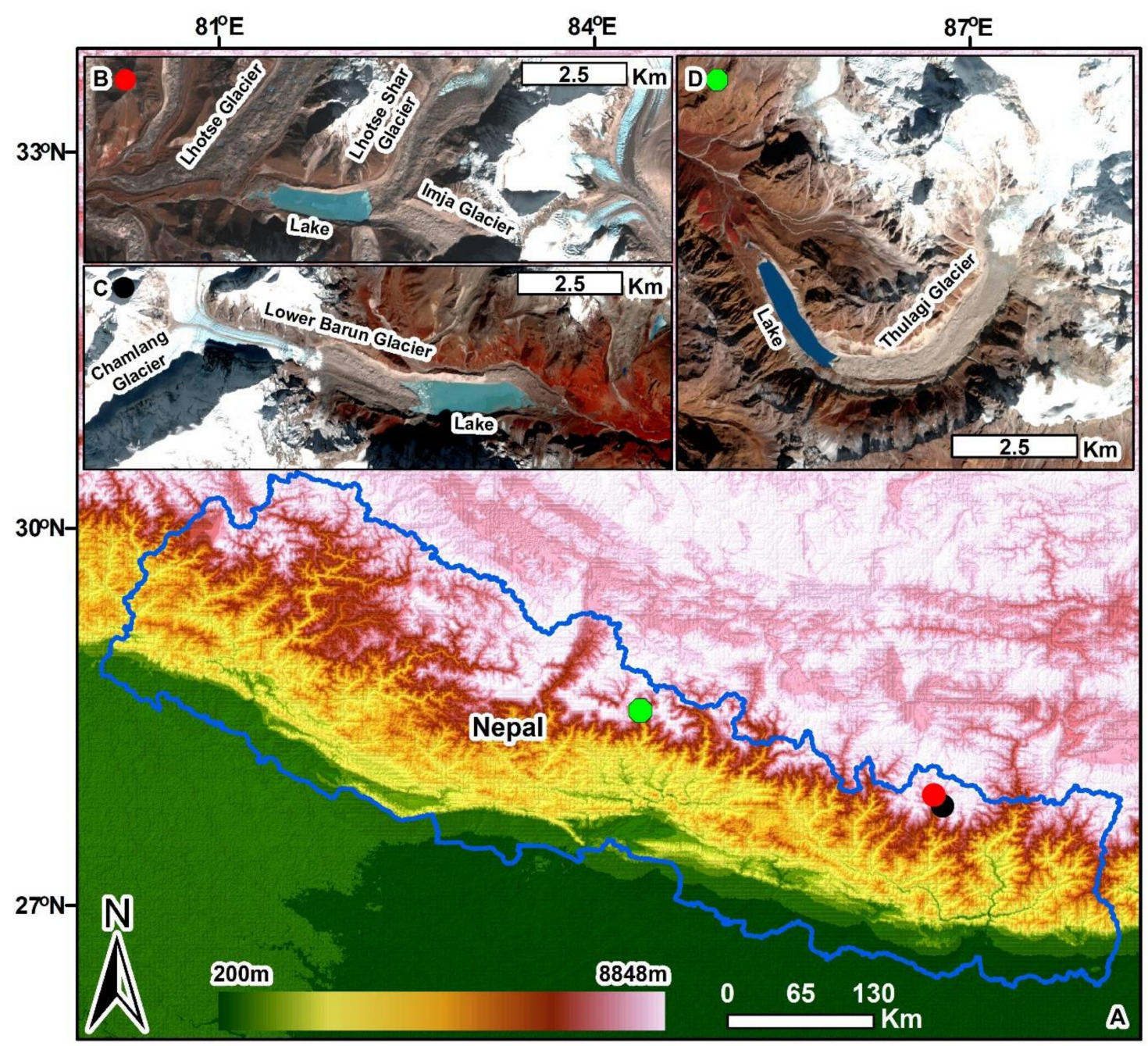

Figure 1. Map of our study area. (A) GTOPO30 topographic hillshade showing Nepal and the surrounding region. Three studied lake locations are marked-Imja (red dot), Lower Barun (black dot), and Thulagi (green dot); Sentinel 2 satellite images (false color infrared bands 8, 4, 3) in insets (B) and (C) (19 November 2016), and (D) (22 November 2016) showing Imja, Lower Barun, and Thulagi Glacier and Lakes along with their tributaries and the nearby glacier.

\subsection{Lower Barun}

The Lower Barun Lake $\left(27^{\circ} 47^{\prime} 51^{\prime \prime} \mathrm{N}, 87^{\circ} 05^{\prime} 26^{\prime \prime} \mathrm{E}\right.$; $4550 \mathrm{~m}$ a.s.l.) is located southeast of Imja Lake in the upper reach of Barun River and adjacent to the Makalu massif. The glacial lake is dammed by an ice-cored moraine to the east and bounded by the calving front of a thick debris-covered glacier to the west [27]. Currently, Lower Barun Glacier is about $2.7 \mathrm{~km}$ in length from the calving front to the base of an icefall, where the slope drastically increases. Images of the lake show consistent calving of the glacier terminus into the moraine-dammed proglacial lake, resulting in many new icebergs (Figure S2).

\subsection{Thulagi}

Thulagi Lake $\left(28^{\circ} 29.24^{\prime} \mathrm{N}, 84^{\circ} 29.17^{\prime} \mathrm{E} ; 4050 \mathrm{~m}\right.$ a.s.l.) is also a proglacial moraine-dammed lake at the terminus of the heavily debris-covered Thulagi Glacier, which is $11 \mathrm{~km}$ long and sourced from the flanks of Manaslu (8156 m a.s.l.). The International Centre for Integrated Mountain Development (ICIMOD) lists this lake as hazardous due to several factors, including the potential for mass movements into the lake and the downstream presence of Tal Village, hydro-electric power 
infrastructure, and a major trekking route. However, Reference [29] categorized Thulagi Lake as a moderate hazard lake based on a comprehensive assessment of GLOF risks, moraine stability, and downstream impacts.

\section{Data, Methods, and Uncertainties}

We consider several measurements for each lake site to assess their evolution and future hazard potential: lake area, elevation change over the end moraine, elevation change and surface velocity of upstream glacier surfaces, sky-view factor, and lake bathymetry.

\subsection{Lake Perimeter Mapping}

We used Landsat multispectral image data from 1975-2017 for Imja and Lower Barun Lakes, and from 1973-2017 for Thulagi Lake to manually digitize the lake perimeters and determine the evolving lake areas. This multi-decadal timeline provides for an extended window into lake development and growth (Table S1).

We performed a rigorous error analysis (and distinguished between accuracy and precision as illustrated in Section 4.1) for glacier and lake area determinations. We started with the detailed treatment of glacier area measurement error [56], and elaborated and adapted the treatment to the study of lake growth. In mapping the contacts between spectrally well-defined material units, such as a clean glacier ice or a lake against an adjoining rocky material, any measurement of the boundary is apt to have a large component of arbitrary absolute error where, for example, scenes are consistently mis-registered by some fraction of a pixel, or the analyst systematically considers the material boundary to be too far on one side of a contact between different tones or hues or spectral band ratios versus another side. Careful manual or automated approaches to delineate the boundary between two discrete units can have a subpixel accuracy of approximately 0.5 pixels. A single analyst or algorithm might systematically tend to draw or compute the boundary of a lake outside the actual lake boundary by up to +0.5 pixels, whereas another analyst or another method might yield a boundary that tends to fall inside the actual lake boundary by up to -0.5 pixels. Hence, this \pm 0.5 -pixel error is an estimate of measurement accuracy. The corresponding lake area accuracy is \pm 0.5 pixels multiplied by the lake perimeter length and sensor's pixel resolution.

The precision (or relative accuracy) of the lake area measurement is different than the above absolute boundary geolocation error. This is the relative error for a controlled approach, i.e., a single analyst using a standard methodology and a single data source to measure the area of a lake over time. The idea is that there will be a systematic error that will be largely repeated from one measurement to another if done by the same analyst and same methodology. This precision metric is the more important error criterion to assess the image-to-image growth of a lake, or to compare the areas of three different lakes. Here we use Equation 22.3 in Reference [56] to quantify the precision for manual digitization involving binary classification of each pixel to either rock, snow /ice, or water, such that an individual pixel may lie randomly as much as +1 or -1 pixel (outboard or inboard) from the lake boundary, but the randomness tends to reduce the overall error for the whole lake:

$$
A_{p, m}: A_{p, m}=\left(j^{-\frac{1}{2}}\right) \cdot(n \cdot m) / A_{g l}
$$

where $j$ is the number of vertices of the digitized polygon, $n$ is the number of pixels defining the perimeter, approximated by the quotient of the perimeter length and sensor resolution, $m$ is the areal spatial resolution of the sensor $\left(\mathrm{m}^{2}\right)$, and $A_{g l}$ is the lake area $\left(\mathrm{m}^{2}\right)$. In this treatment, $j \leq n$.

\subsection{Digital Elevation Model (DEM) Analysis}

We generated a high-resolution DEM time series for each lake site using available sub-meter stereo satellite imagery from the DigitalGlobe archive (GeoEye-1, WorldView-1/2/3) and the methodology 
described in Reference [57]. Both "along-track" and "cross-track" DEMs were generated to improve temporal coverage [58,59].

We used the methodology described in Reference [57] for DEM co-registration. A weighted-average composite "reference DEM" with improved horizontal and vertical accuracy was generated from stacks of 2-m DEMs for each site. A set of static reference surfaces (i.e., exposed valley walls) was identified using an $80 \%$ threshold applied to a global 30-m bare ground percentage product [60]. An iterative closest point (ICP) co-registration routine [57] was then used to solve for a robust three-dimensional (3D) translation to align each individual DEM to the reference DEM composite over these static surfaces with the tools in the demcoreg software package (https:/ / github.com/dshean/demcoreg).

Eulerian elevation differences were calculated for pairs of overlapping DEMs, and elevation change rates in units of $\mathrm{m}$ /year were calculated based on the time interval between the two DEMs. Individual DEM coverage is variable (i.e., only a subset of DEMs cover the entire lake at each site). We also calculated long-term elevation change for each site using the 1-arcsecond (30-m) SRTM-GL1 (Shuttle Radar Topographic Mission-Global 1) product from 11 February 2000 and the 2-m DEM from 11 February 2016 for Imja, 18 October 2015 for Lower Barun, and 7 December 2014 for Thulagi. The normalized median absolute deviation (NMAD) [61] was calculated for a random selection of $\sim 50$ stable points over static reference surfaces in these SRTM and DigitalGlobe elevation-change products to estimate uncertainties of $\pm 0.67 \mathrm{~m}$ /year for the Imja region, $\pm 0.82 \mathrm{~m} /$ year for the Lower Barun region, and $\pm 0.88 \mathrm{~m}$ /year for the Thulagi region.

We analyzed the sky-view factor, which is a proxy for diffuse irradiance and measures the proportion of sky visible from a given point irrespective of the overcast conditions [62], using ATCOR 3 v.9.1.2 for the mountainous terrain (https://www.rese-apps.com/index.html), and an 8-m weighted-average DEM composite derived from 2010-2016 WorldView and GeoEye DEMs, with residual gaps filled with the SRTM-GL1 DEM data. To avoid artifacts over the lake area, we masked out the lake perimeter and hydro-flattened the area by filling the minimum DEM values extracted from the masked area. Details for the software and methodology can be found in Reference [63].

\subsection{Glacier Velocity}

Glacier surface velocity partly controls the development of supraglacial lakes [64], which impacts the melting pattern and ice elevation changes that are critical for the evolution of proglacial lakes. The pattern of ice flow also provides an understanding of whether the lake has expanded far enough into the glacier trunk to significantly increase surface gradients and trigger a drawdown increase in ice discharge and rapid glacier retreat [65].

We measured glacier velocity for two time periods using feature-tracking of yearly orthorectified image pairs with COSI-Corr [66-68] (Table S1). The image correlation calculates horizontal surface displacements between two images separated in time. A variety of Landsat band options can be used for this correlation. We obtained the consistent results and the lowest average error with the NIR band $(0.85-0.88 \mu \mathrm{m}$, Landsat 8; 0.77-0.90 $\mu \mathrm{m}$ Landsat 7; 0.76-0.90 $\mu \mathrm{m}$ Landsat 4, 5) compared to other multispectral bands or the panchromatic band.

Feature tracking was conducted using a search window size between 64 and 128 pixels, with a step size of one pixel $(30 \mathrm{~m})$. Output included displacement maps in east-west $(x)$, north-south $(y)$ directions and their corresponding signal-to-noise ratios (SNR). Accuracy was determined using mean and standard deviations of these components over stable off-glacier regions. This analysis indicated apparent motion over bedrock areas of $\pm 2.09 \mathrm{~m}$ /year for the Imja and Lower Barun regions and $\pm 2.04 \mathrm{~m}$ /year for the Thulagi region. For final comparative analysis, a common practice of maximum velocity magnitude threshold filter [69] of $60 \mathrm{~m}$ /year was adopted. We also masked pixels showing an SNR lower than 0.9, and pixels showing local reversal in $x, y$ values using median filter [70]. To fill the holes created by these filters, we applied a $5 \times 5$ smoothness filter except for the small area in the accumulation zone of Imja and Thlagi Glaciers where the velocity was extremely high. More details 
about the methodology related to velocity measurement and uncertainty analysis can be found in Reference [71].

For centerline glacier velocities, we generated an automated polyline running at the center of the glacier with reference to the corresponding year's glacier boundary. These may not always reflect the fastest flow line for the glacier but, given the input coming from two different sources in the Imja Glacier system and separate ice and debris flow from Chamlang ridge dictating the flow at the lower ablation zone of Lower Barun, the geometric centerline was considered for a representative analysis.

\subsection{Bathymetry}

Echo sonar soundings across Imja Lake and nearby Amphulapche Lake (mid-late October 2014), and Lower Barun (late October 2015) were acquired from an inflatable kayak-mounted SyQwest Hydrobox sonar sensor. The survey was conducted along transverse and longitudinal transect lines designed prior to the survey and monitored in real time during surveying (Figure 2). Large icebergs were avoided and therefore some survey lines deviate from the grid. The sonar transducer was operated at $210 \mathrm{kHz}$ (7 mm wavelength). Sensor settings for optimal data-return quality included sound velocity (1400 $\mathrm{m} \mathrm{s}^{-1}$ based upon $0{ }^{\circ} \mathrm{C}$ water temperature). The sensor was mounted amidships and with ample draft, in our case $25 \mathrm{~cm}$, well below the shallow draft of the wide-keeled kayak. For positional control, all sonar soundings were paired with latitude/longitude coordinates supplied by a Trimble GeoXH GPS unit with National Marine Electronics Association (NMEA) output at $1 \mathrm{~Hz}$. Our survey amassed in excess of 50,000 sounding points for Imja and Lower Barun Lakes, and 4000 points for Amphulapche Lake; however, $30-40 \%$ of these points were omitted due to either: (i) missing GPS signals, (ii) spurious sonar sounding data dropouts where depth equals zero; (iii) "invalid" soundings as classified by a Hydrobox sensor processor; (iv) quasi-systematic positional duplicate points with variable depths due to: (a) data collected at sonar sensor ping frequency $>1 \mathrm{~s}^{-1}$, or (b) baud rate incompatibility between GPS hardware cabling (4600 baud) and sonar NMEA required output (9600 baud).

We used an Unmanned Surface Vessel (USV, Oceanscience ZBoat) to acquire sonar soundings for a high-density survey across the western portion of the primary Imja Lake and the first connected small lake west of Imja (Figure 2). The USV was operated from the lake shore at the speed of 3-4 knots $(1.5-2.0 \mathrm{~m} / \mathrm{s})$ and 9654 total sounding points were collected. The USV data were acquired with a CEE HydroSystem survey grade CEEPULSE echosounder at an operating frequency of $200 \mathrm{kHz}$, with a transducer beam width of $9^{\circ}$, a sound velocity of $1350 \mathrm{~m} / \mathrm{s}$ for computing depth, and a data update rate of $1 \mathrm{~Hz}$. Data outputs were posted in industry standard NMEA depth below transducer (DBT) format and later merged with the kayak-mounted echosounders data and plumb line data. The USV was unavailable during the Lower Barun and Thulagi surveys. Additionally, we also used a set of plumb line measurements taken through augured holes where the lake was frozen during our survey. At Lower Barun Lake, we manually recorded depth and positions at 30 different equally-spaced points due to the loss of GPS position fix in the kayak (dots in Figure 2).

The Thulagi Lake bathymetric survey (late October 2017) was conducted using a Furuno 235DT-PSE mounted to the side of a kayak in a stable position. Data were collected at an operating frequency of $235 \mathrm{kHz}$, with a transducer beam width of $12^{\circ}$, and data update rate of $1 \mathrm{~Hz}$. Data gaps are related to floating ice and a faulty cable connection. In total, we used 28,268 sounding points from Thulagi Lake in our bathymetric analysis.

Bathymetric models were created within ArcGIS 10.3 using natural neighbor interpolation [72,73]. The results were posted on a 1-m grid and lake volumes were calculated. Bathymetric modeling requires a shoreline with zero depth. Since no 'zero depth' data were collected from the outline extent of the lakes, we generated lake extents using multispectral satellite imagery acquired closest to the survey dates. Points were generated at $1-\mathrm{m}$ intervals along the derived lake boundary polylines and assigned depths of zero. These points were appended onto the validated lake bathymetric points to complete the sounding databases for bathymetric modeling. Zero depth points were removed at the glacier calving front to avoid forcing the interpolated bathymetry to zero [73]. Additionally, zero depth 
points were added along the glacier medial moraines for $\sim 500 \mathrm{~m}$. This was required since the natural neighbor method does not interpolate outside the convex hull, and therefore would not otherwise interpolate bathymetry to the calving front.
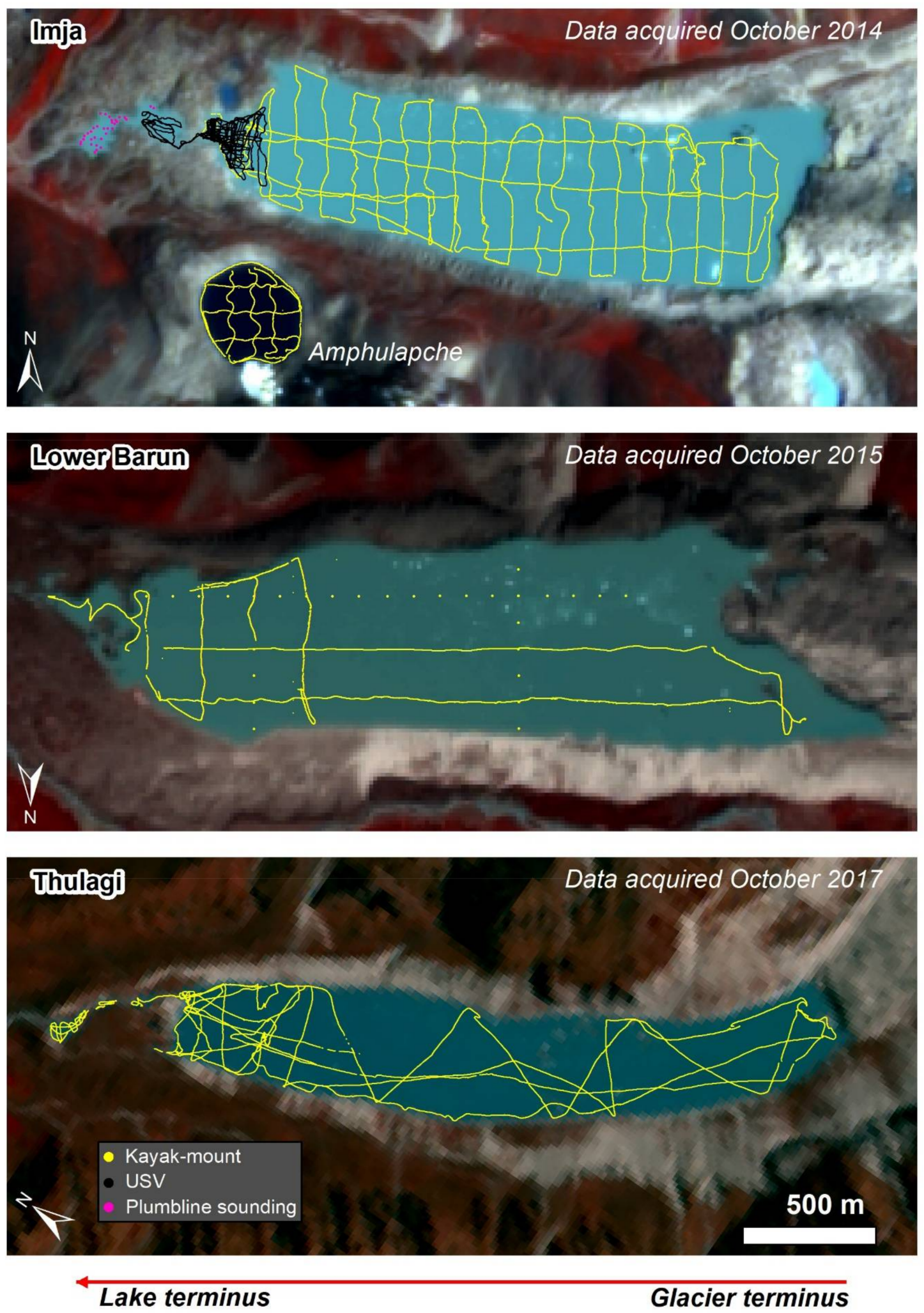

Figure 2. Vessel tracks collecting bathymetric data at each of these lake locations. Yellow dots in the middle figure (Lower Barun Lake) shows points where depth and location data were collected manually. 
For uncertainty analysis, we used water depth-normalized 2- $\sigma$ standard deviation [74]. Tie-lines were run perpendicular to the trackline and it was found that $2 \sigma$ standard deviation across the along-track artifacts is about $0.8 \%$ of water depth and the mean depth uncertainty for all tie-line to track data is $0.2 \%$ of water depth. Additionally, the echosounder data accuracy is suggested as $0.01 \mathrm{~m} \pm 0.1 \%$ of depth. The acoustic velocity due to water temperature has relatively high uncertainty, as temperature likely varies between $0{ }^{\circ} \mathrm{C}$ and $4{ }^{\circ} \mathrm{C}$ in the lake. Moreover, for $\pm 2{ }^{\circ} \mathrm{C}$ temperature uncertainty, the corresponding depth error is about $\pm 0.7 \%$ (e.g., about $\pm 0.2 \mathrm{~m}$ for a 30 -m water depth). We also assumed another $0.1 \%$ of depth uncertainty due to nearshore rock outcrops and missing zero depth data, making our overall uncertainty for bathymetric analysis $\pm 1.9 \%$ of water depth. We noted that for side-scan sonar systems, lake thermal stratification and associated temperature and sound speed uncertainties of this magnitude can produce large but unknown sound wave refractions and thus large positional errors, but for near-nadir projecting sound transmission, refraction-induced positional errors are very small.

\section{Results and Analysis}

\subsection{Moraine-Dammed Proglacial Lake Evolution}

Multiple field and remote sensing surveys of Imja Lake have been conducted in the last four decades. By May 2009 [26], Imja Lake was regarded as one of the fastest-growing lakes in the Himalaya with an area of $1.06 \mathrm{~km}^{2}$. In this study, we used Landsat images to measure approximate annual lake growth from 1975 to 2017 (Figure 3 and Figure S1). During the 42 years since 1975, the surface area increased from $0.19 \mathrm{~km}^{2}$ to $1.30 \mathrm{~km}^{2}$, an average growth of about $0.03 \mathrm{~km}^{2}$ per year, which is consistent with previous surveys (see Section 5.1). These data suggest an increase in areal growth rate, especially in the last decade (Figures 3 and 4).

The growth of Lower Barun Glacial Lake from small supraglacial lakes to a large proglacial lake was observed from 1975-2017 using Landsat imagery (Figures 3 and 4 and Figure S2). Our analysis documents the retreat of Lower Barun Glacier to be concurrent with the growth of the proglacial lake area, which increased from $0.04 \mathrm{~km}^{2}$ to $1.8 \mathrm{~km}^{2}$, an average increase of $0.04 \mathrm{~km}^{2}$ per year. Proglacial lake growth occurred rapidly, starting from just a few small supraglacial lakes which quickly coalesced and expanded as the glacier retreated [75]. Imja Lake was commonly thought to be the fastest growing lake in the region [24]; however, our analyses suggest that the growth rates at Lower Barun and Imja were roughly the same until about 2000, after which Lower Barun grew much more rapidly. From 2000 to 2017 , the lake area increased by $34 \%$. Additionally, over the past three years Lower Barun Lake has grown by $0.19 \mathrm{~km}^{2}$ (50\% faster growth over the long-term average annual growth rate), reflecting the accelerating growth evident in Figure 3.

Thulagi Lake was observed from 1973-2017 using Landsat imagery (Figures 3 and 4 and Figure S3). During those 44 years, the moraine-dammed proglacial lake increased in surface area from $0.4 \mathrm{~km}^{2}$ to $0.9 \mathrm{~km}^{2}$, with most of the growth occurring until the mid-1990s. Thulagi Lake growth was slower than the other two lakes with a roughly linear trend until 2005, and limited change between 2005 and 2017. Our fieldwork in October 2017 at Thulagi Lake took place at the end of an active calving season in the July-September timeframe (similar to more common events at Imja and Lower Barun Lakes), but these have been rare or mainly smaller events at Thulagi in the period since 2000, as seen in the satellite images (Figure S3). 


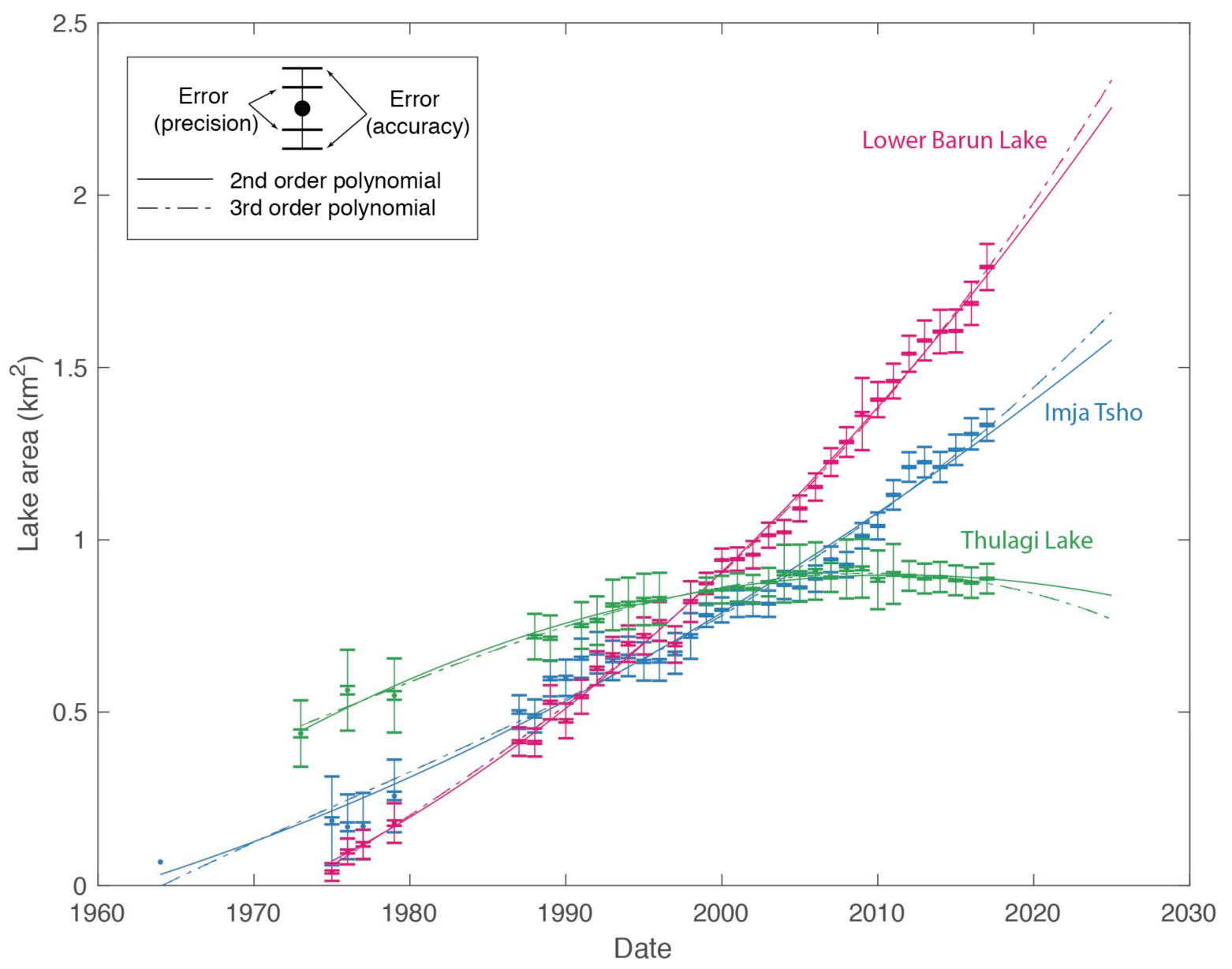

Figure 3. Area change of Imja, Lower Barun, and Thulagi Glacial Lakes as monitored using Landsat satellite images from the early mid-1970s to 2017. Second- and third-order polynomial projections are fitted to each lake area data to extrapolate possible future growth up to 2025. Two different bars show errors relating to accuracy (large error bars) and precision (small bars from Equation (1)), as discussed in Section 3.1. Data for the Imja Lake area in 1964 was obtained from Reference [75] with no available error estimates.

\subsection{Topographic Analysis}

Elevation changes were determined over the glaciers and ice-cored end moraine from 2000 to $\sim 2015 / 2016$ (Figure 5). Our results show surface lowering at the glacier terminus, as well as measurable lowering at the end moraine, especially at Lower Barun and Imja Lakes.

The thinning rate in the lower 1.5- $\mathrm{km}$ ablation zone of Lhotse Shar Glacier, which feeds into Imja Lake, is in the range of -0.1 to $-3.0 \mathrm{~m} /$ year, with an average rate of $-1.31 \mathrm{~m} /$ year. At Lower Barun this rate ranges between -0.4 to $-4.5 \mathrm{~m} /$ year with an average rate of $-2.21 \mathrm{~m} /$ year, while at Thulagi Glacier the thinning rate in the lower 2.5 to $3 \mathrm{~km}$ of the ablation zone ranges between -0.51 to $-5.29 \mathrm{~m} /$ year and the average rate is $-1.9 \mathrm{~m} /$ year. Of the three lakes, Lower Barun Glacier shows the highest elevation change rate magnitudes.

Manual inspection at each location indicates that the pixels showing the highest annual changes are less than $5 \%$ of the total pixels and mostly associated with DEM artifacts or extreme local changes near rapidly evolving features (e.g., ice cliffs, thermokarst). Most of the pixels around the terminus region that are not associated with the supraglacial ponds and ice cliffs show average elevation changes of $-1.28 \mathrm{~m} /$ year, $-1.88 \mathrm{~m} /$ year, $-1.41 \mathrm{~m} /$ year for Lhotse Shar, Lower Barun, and Thulagi, respectively. The average lowering rates over glaciers are significant. The ablation areas with thinner debris-covered 
glaciers are lowering faster than the debris-free accumulation areas and the thick debris-covered, ice-cored end moraine dams of the lakes.
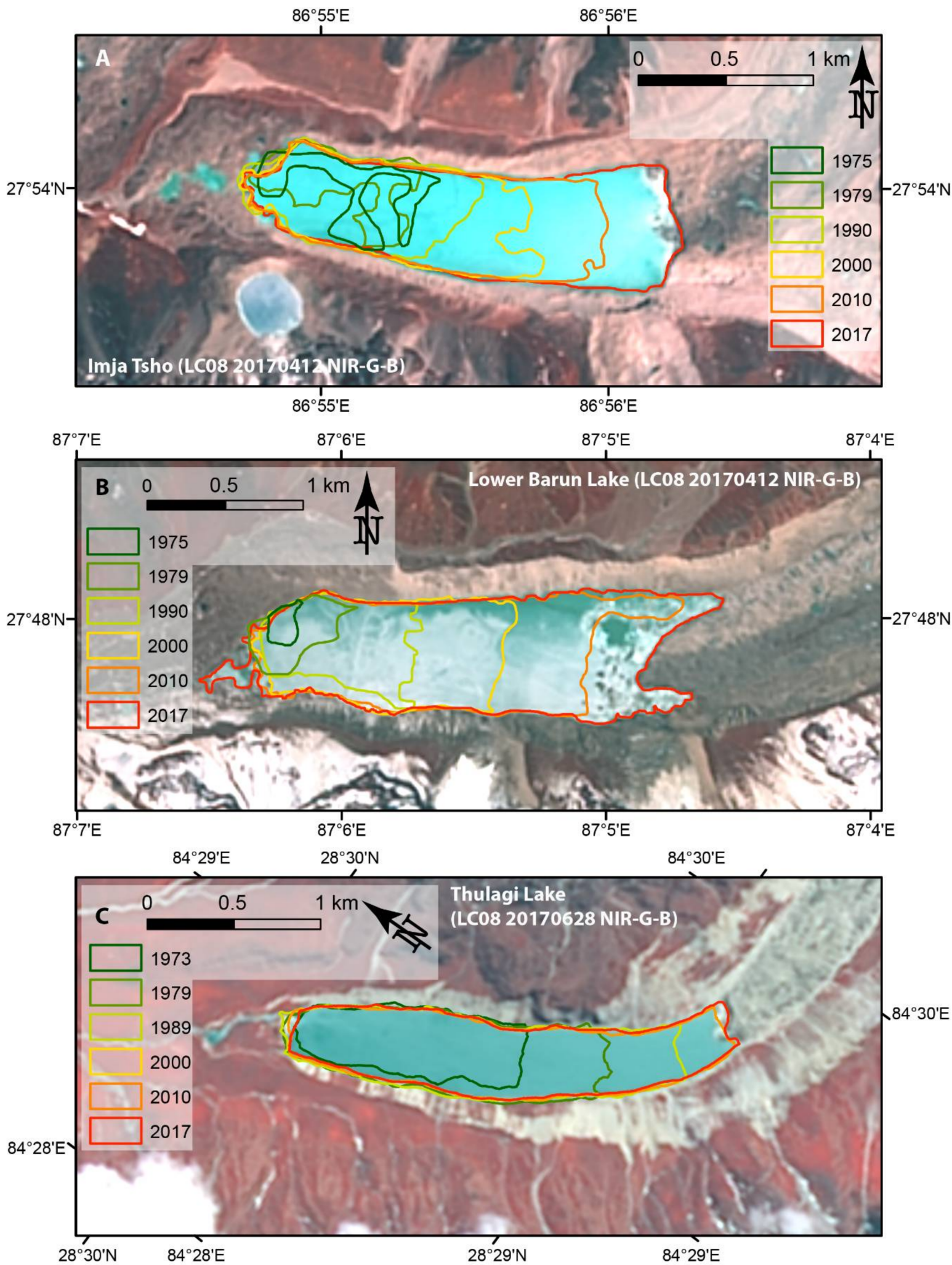

Figure 4. Long-term evolution of lake perimeter with 4-11-year intervals for (A) Imja Lake, (B) Lower Barun Lake, and (C) Thulagi Lake. See Table S1 for full list of observations. 


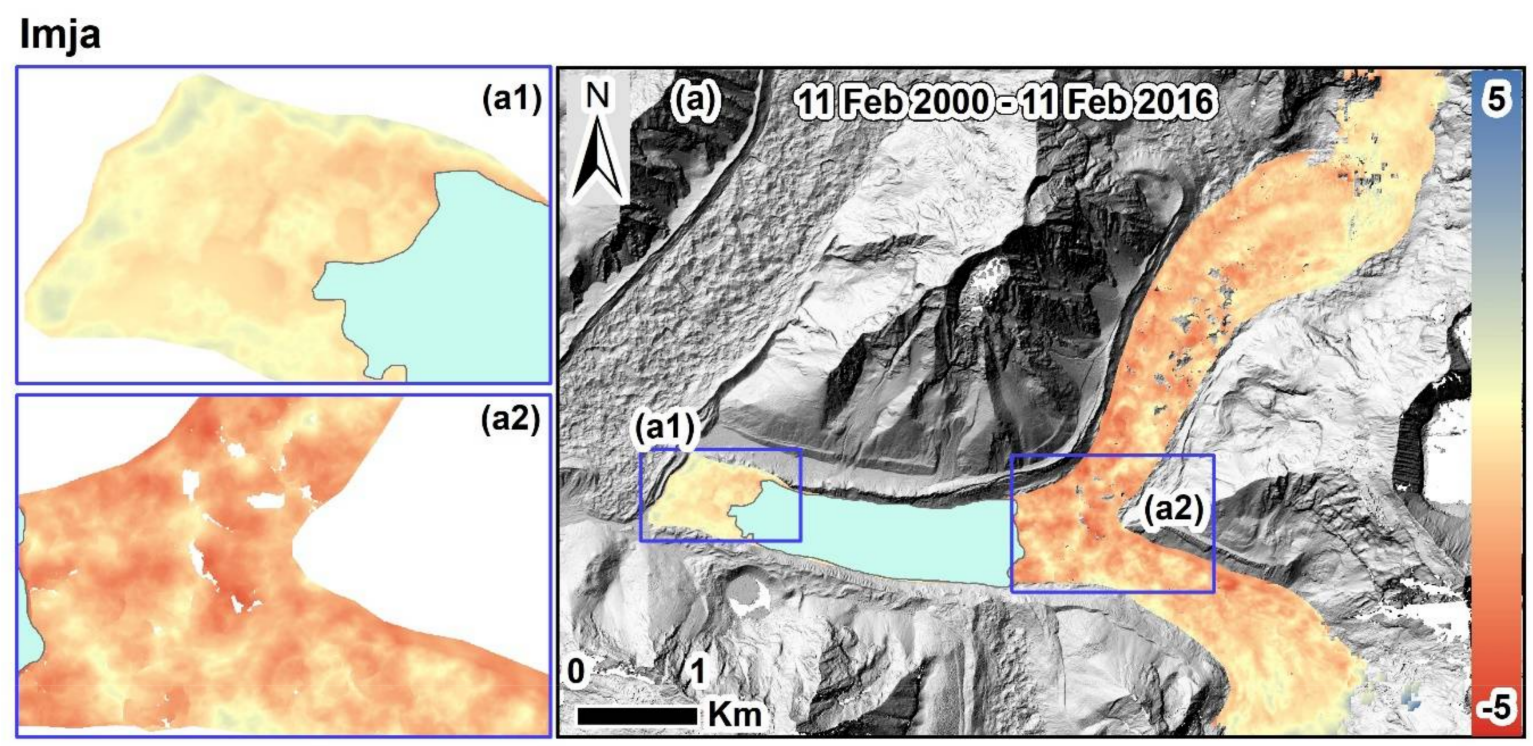

Lower Barun

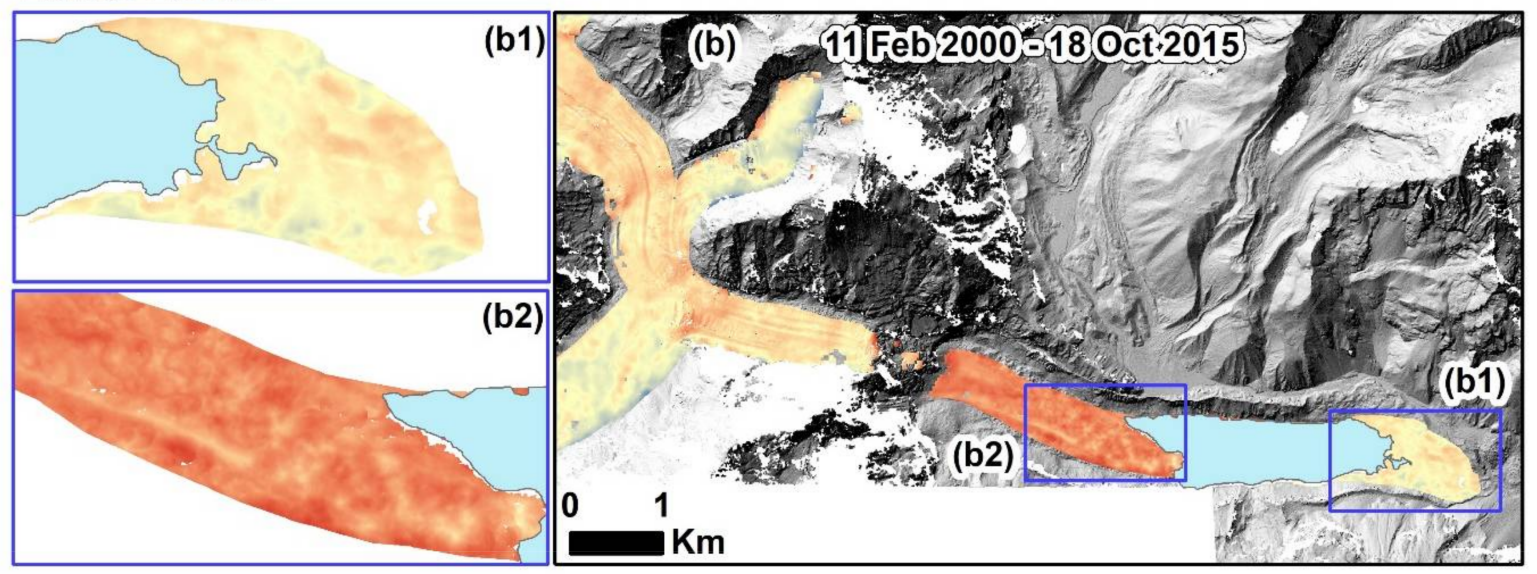

\section{Thulagi}

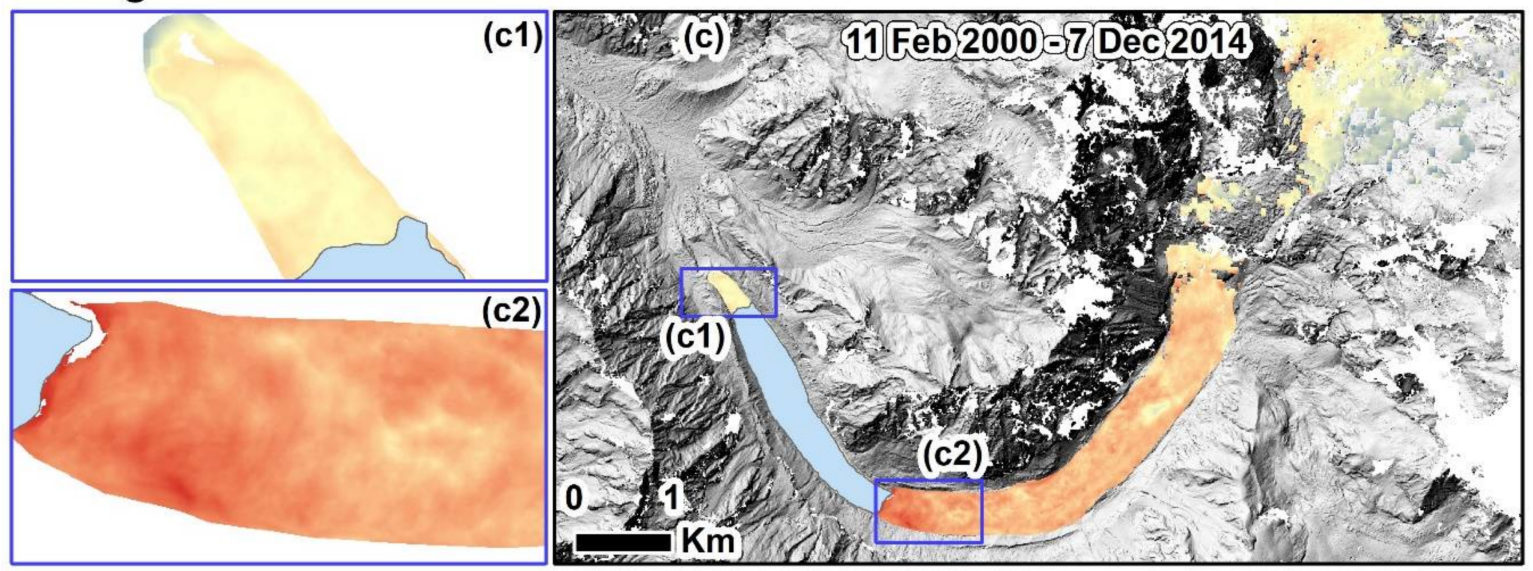

Figure 5. Elevation change rates (m/year) for the three study sites from 2000 to 2014-2016.

In addition to analyzing the elevation changes of glacier surfaces, we also analyzed elevation changes at the end moraines. Of particular concern would be the loss of ice over time from those end moraines containing ice, resulting in the subsidence or collapse of the moraine, possibly compromising the moraine's containment strength. Our field observations documented visible ice in the end moraine 
both at Imja and Lower Barun beneath about $1 \mathrm{~m}$ of debris (Figure 6). Similar debris-covered ice cliffs were observed up close-nearly pure ice, covered by less than a meter of debris—in October 2010 in Lhotse Glacier's end moraine where it nearly converges with Imja Lake's damming end moraine. Without subsurface geophysical investigations, it is difficult to assess the prevalence and depth of this buried ice in other parts of the moraines, but previous studies at Thulagi and Imja suggest the presence of widespread ice-cored moraines [76,77]. We suggest that the areas that show the largest lowering rates in the DEM difference maps likely contain buried ice beneath thinner debris layers. The highest rates of elevation change over the end moraines at Imja, Lower Barun, and Thulagi are $-1.9 \mathrm{~m} /$ year, $-1.5 \mathrm{~m} /$ year, and $-1.2 \mathrm{~m} /$ year, respectively. However, the average elevation change rate at the end moraine at all three locations is below $-0.5 \mathrm{~m} /$ year. The relative rate of elevation change increases substantially around the supraglacial lakes and ice cliffs both on the glacier ablation zone and ice-cored end moraine (Figures 5 and 6).
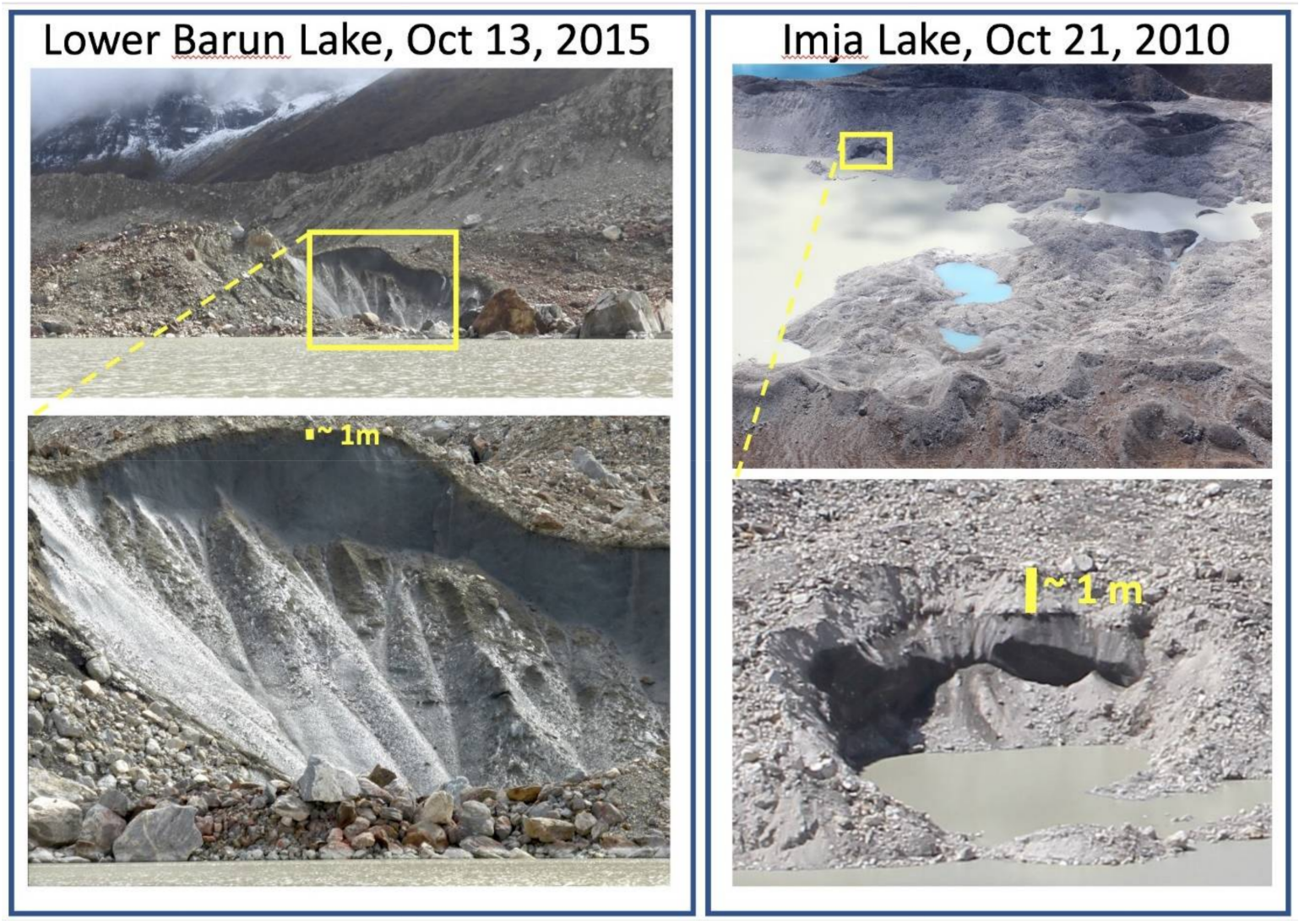

Figure 6. Ice-cored moraine.

We also used DEMs to analyze the sky-view factor and our results indicate that the Thulagi Lake area receives only 45-75\% irradiance, lower than that received by Lower Barun (83-86\%) or Imja (86-88\%) Lakes (Figure 7). Detailed radiative transfer modeling and its impact on the glacier melting and lake evolution is beyond the scope of this paper. However, we analyzed the lower $2.5 \mathrm{~km}$ of the terminus region of each glacier to understand the controls of a sky-view factor on the terminus region. Our analysis indicates that Thulagi's terminus region receives lower irradiance (63-79\%; peak value $75 \%)$, which is statistically significant $(p=0.05)$, compared to the irradiance received by Lower Barun (67-84\%; peak value 79\%) and Imja (67-88\%; peak value 81\%) Lakes. 

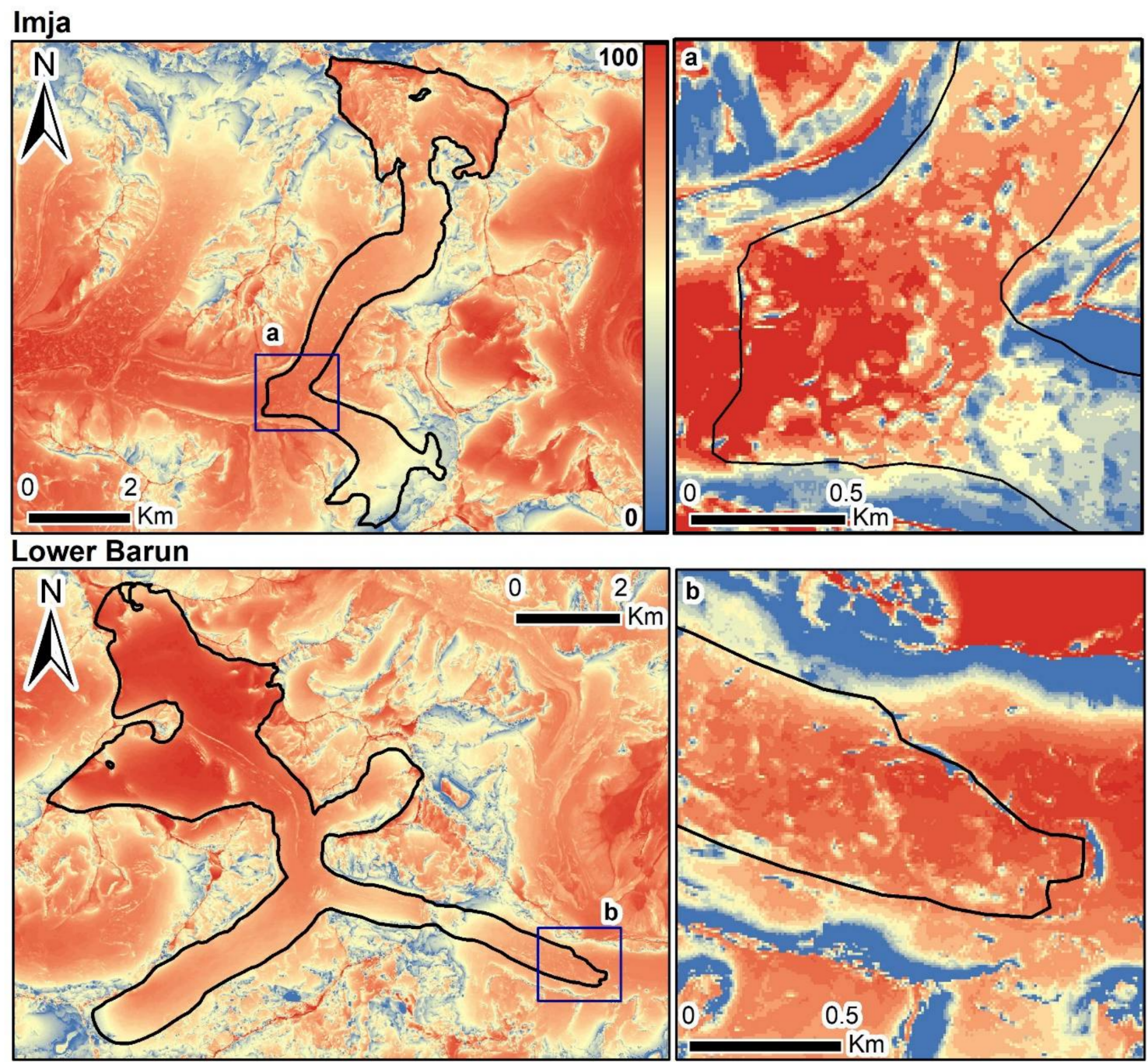

\section{Thulagi}
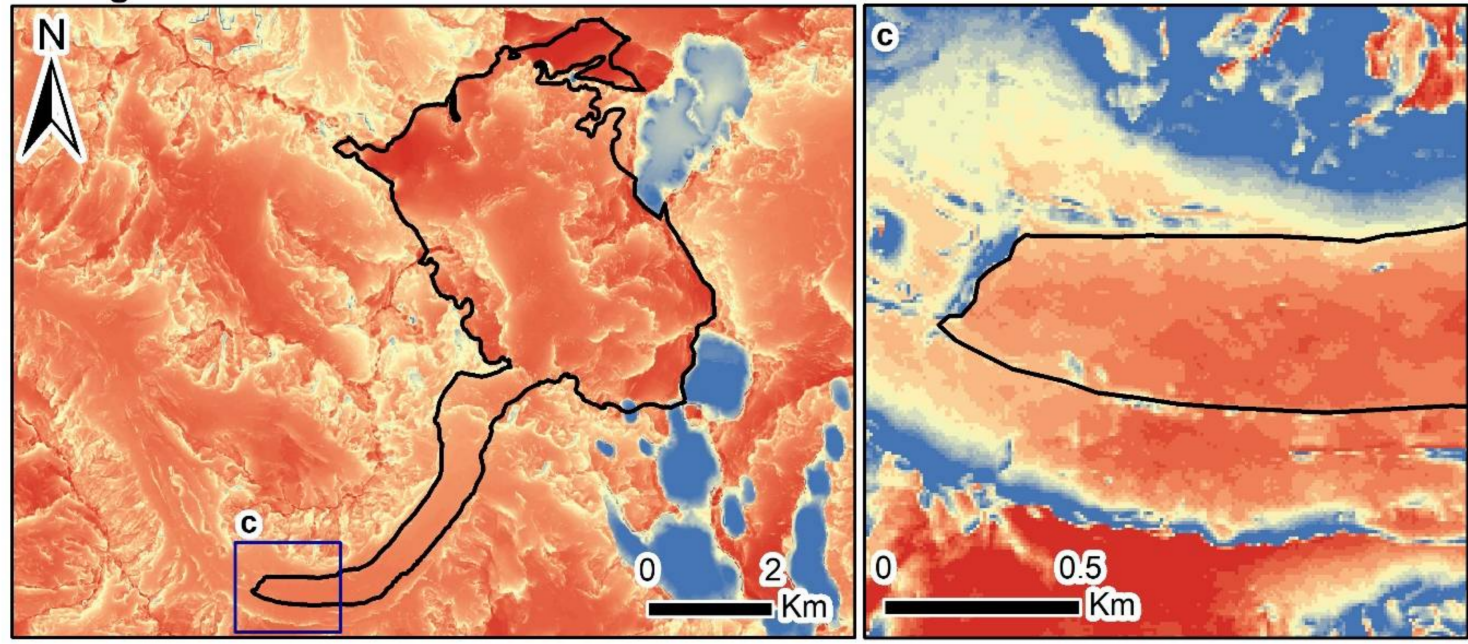

Figure 7. Normalized distribution showing a sky-view factor percentage. Blue tones represent relatively high topographic shielding of diffuse skylight irradiance and red tones indicate a full hemispherical view. A zoomed view of the terminus region (blue rectangle) stretched with a standard deviation of 1 to reflect the range of distribution and smooth texture at Thulagi due to the relative absence of supraglacial ponds and ice cliffs compared to the Imja and Lower Barun Glaciers. 


\subsection{Glacier Surface Velocity}

The Imja glacier system has two active tributaries-Imja to the south, which shows slow ice movement (1-10 m/year), and Lhotse Shar to the north, where peak velocity reached approximately $60 \mathrm{~m} /$ year (Figure $8 \mathrm{a}-\mathrm{c}$ ). The velocity in the areas where these two sections converge ranges between 10-15 m/year but drops to $\sim 5 \mathrm{~m} /$ year near the calving front. Our analyses indicate that the majority of the ice reaching the glacier terminus is sourced from Lhotse Shar Glacier. Results also show that both tributaries display similar temporal variability, except for the zone on Lhotse Shar Glacier, where the debris-covered surface has transitioned into a debris-free area (exposed ice) marked as the transition zone (TZ) in Figure 8a. The region between the headwall (HW) and TZ receives most of the snow and ice nourishment - in addition to much rock debris - in the form of avalanches from the nearby high valley walls and shows considerable annual variation in velocity. The centerline velocity profiles and the displacement map show a recent decline in velocity mostly in the lower $\sim 4 \mathrm{~km}$ of the ablation zone.
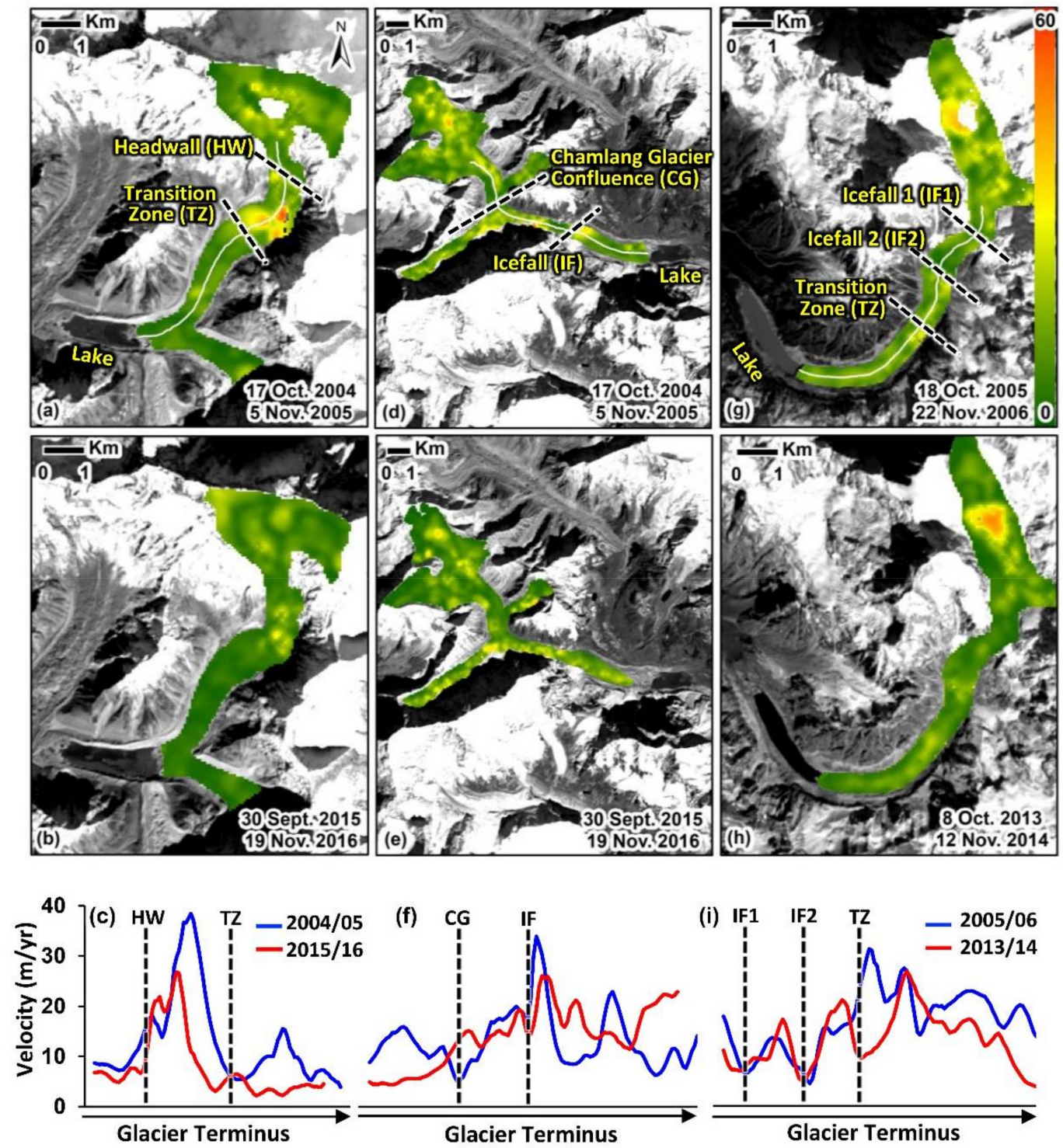

Figure 8. Displacement maps (m/year) and two-point boxcar average velocity measured along the centerline of $(\mathbf{a}-\mathbf{c})$ Imja and Lhotse Shar Glaciers, $(\mathbf{d}-\mathbf{f})$ Lower Barun Glacier, and (g-i) Thulagi Glacier. Headwall (HW), transition zone (TZ), Chamlang Glacier Confluence (CG), icefall (IF), icefall-1 (IF1), and icefall-2 (IF2) represent markers where a change in flow speed was observed. 
The velocity profile for Lower Barun Glacier shows a different pattern from the top of the accumulation zone to the terminus compared to Imja Glacier (Figure 8d-f). Lower Barun Glacier also receives a significant contribution from the Chamlang Glacier tributary, which enters the main glacier trunk $\sim 2 \mathrm{~km}$ from the Lower Barun icefall (IF). Unfortunately, image correlation failed over much of this tributary due to severe shadowing and snow cover in the Landsat images. Our results, however, show that the average surface velocity of the main glacier above the Chamlang Glacier (CG) confluence was higher in the period of 2004-2005 (10-18 m/year) than in 2015-2016 (8-13 m/year). However, down-glacier from CG, the results indicate increasing speed possibly due to increased discharge from Chamlang Glacier. Relatively high velocities are observed from the icefall to the terminus. At the 2015-2016 terminus location, the surface velocity increased from $12 \mathrm{~m}$ /year to $22 \mathrm{~m}$ /year.

The average surface velocity of Thulagi Glacier downstream of the transition zone (TZ), where the glacier transitions into the debris-covered surface, is (7-32 $\mathrm{m}$ /year) higher than the upper half of the glacier for which centerline profile was generated (7-23 $\mathrm{m} /$ year). Our results show rapid spatial increases in surface movement (almost doubling) at around $5 \mathrm{~km}$ from the current terminus position because of an icefall-2 (IF2), similar to what we observed upwards from the terminus of Lower Barun Glacier (Figure 8g-i). The glacier reflects a pattern of high and low velocity throughout the ablation zone. The first such pattern appears right after (below) icefall-1 (IF1), the second below IF2, and the third below the TZ. The highest ice velocities occur around the TZ. These high velocity values decline as the glacier flows towards the heavily debris-covered terminus zone. From an average decadal perspective, the 2005-2006 image shows similar velocity trends in the last $3 \mathrm{~km}$ of the ablation zone, but the 2013-2014 image shows a sharp decline similar to that of the Lhotse Shar Glacier. The ice velocity at the terminus during the recent time period was roughly half the observed surface velocity of the previous time period.

\subsection{Bathymetry}

In October 2014, Imja Lake had an area of $1.28 \mathrm{~km}^{2}$, a maximum depth of $150 \mathrm{~m}$, and a volume of $78.4 \times 10^{6} \mathrm{~m}^{3}$, while the smaller Amphulapche Lake located south of Imja had an area of $0.12 \mathrm{~km}^{2}$, maximum depth of $66 \mathrm{~m}$, and contained $3.2 \times 10^{6} \mathrm{~m}^{3}$ of water (Figure 9). The eastern section (upper) of two smaller lakes along the spillway on the end moraine attained a depth of $18 \mathrm{~m}$. The Imja Lake volume includes the main lake plus the connected outlet lake on the western end, which is less than $10 \mathrm{~m}$ deep.

The bathymetric measurements conducted at Lower Barun Lake in 2015 were the first reported observations for the lake. It is the biggest and deepest of the three lakes discussed here (Figure 9), and deeper also than Tsho Rolpa, which also has been surveyed [26]. The maximum depth is $205 \mathrm{~m}$, and it contains $\sim 112.3 \times 10^{6} \mathrm{~m}^{3}$ of water, which makes Lower Barun Lake both $27 \%$ deeper and $27 \%$ larger volumetrically than Imja Lake. Due to variations in the number and density of soundings, the level of smoothness between bathymetric modeling at Imja and Lower Barun Lakes varies slightly, but both reflect similar lakebed morphology characterized by a gently sloping (deepening) bed from the lake terminus to the mid-point, followed by a slightly steeper decline towards the glacier terminus (Figure S4). In both lakes, the deepest part of the trough is located closer to the calving front. Such upvalley deepenings are common in glacial valley systems at the confluence of tributary glaciers.

Thulagi Lake has a volume of $36.1 \times 10^{6} \mathrm{~m}^{3}$, with a maximum depth of $76 \mathrm{~m}$ that is approximately $50 \%$ and $30 \%$ of the maximum depth at Imja and Lower Barun, respectively (Figure 9). The apparent bottom shape, however, is affected by a sparse dataset, where interpolation may affect the results. Thulagi Lake's bottom profile ranges from $0.3 \mathrm{~m}$ around the terminus to as much as $65 \mathrm{~m}$ deep just $450 \mathrm{~m}$ upvalley from the lake terminus. Going upvalley, the lake bottom then sharply inclines back to the mid-50 m range, and then declines again to a mid- $60 \mathrm{~m}$ depth. Most of the central section of the lake along the longitudinal transect shows depths between $60-70 \mathrm{~m}$, and locally up to $75 \mathrm{~m}$, which reflects a different longitudinal lake bottom morphology compared to the other two lakes (Figure S4). The deepest section of the lake appears as a narrow 300-m long longitudinal trough located 
about $750 \mathrm{~m}$ from the glacier terminus. The central section of Thulagi Lake does not show a gradual deepening towards the glacier terminus as at Imja and Lower Barun Lakes. Rather, in our interpolated bathymetric map, the bed appears undulating, characterized by three major trough areas, but the deepest points are located within $500 \mathrm{~m}$ of the glacier terminus, like Imja and Lower Barun Lakes. However, adjacent to the glacier terminus the lake depth is shallow, quite different than the other two lakes.

\section{Imja}
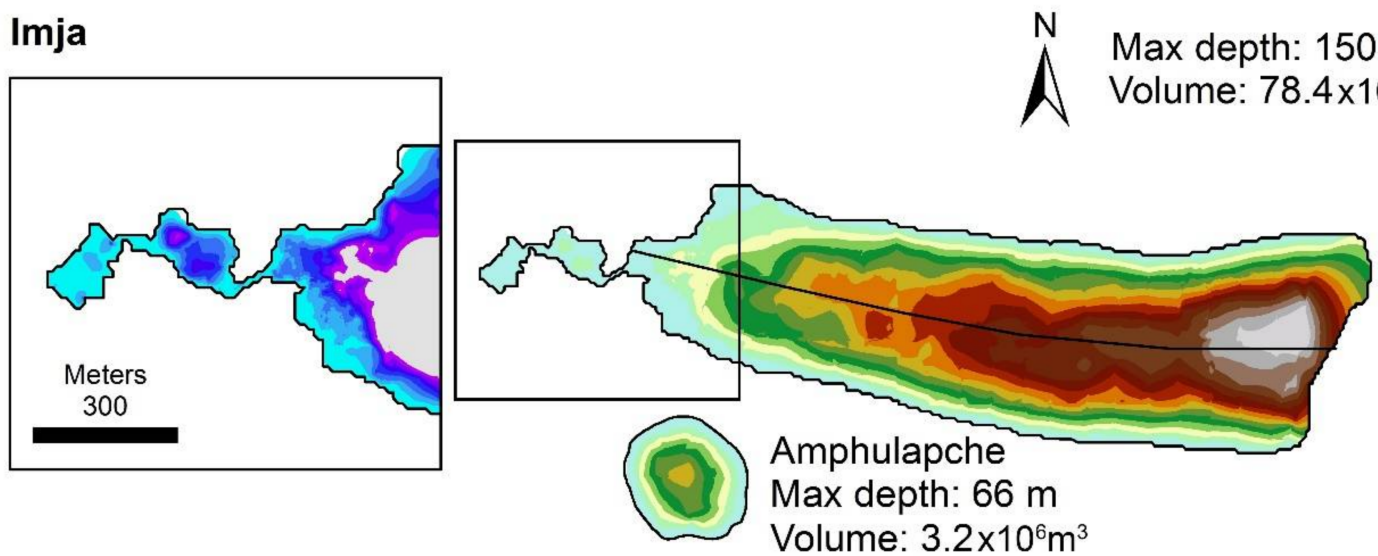

\section{Lower Barun}
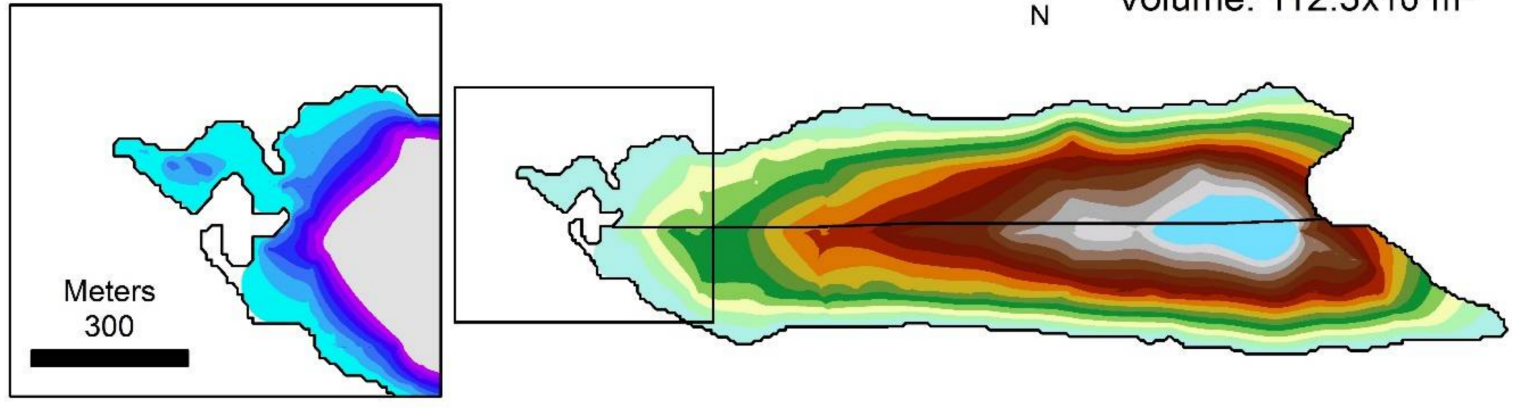

\section{Thulagi}

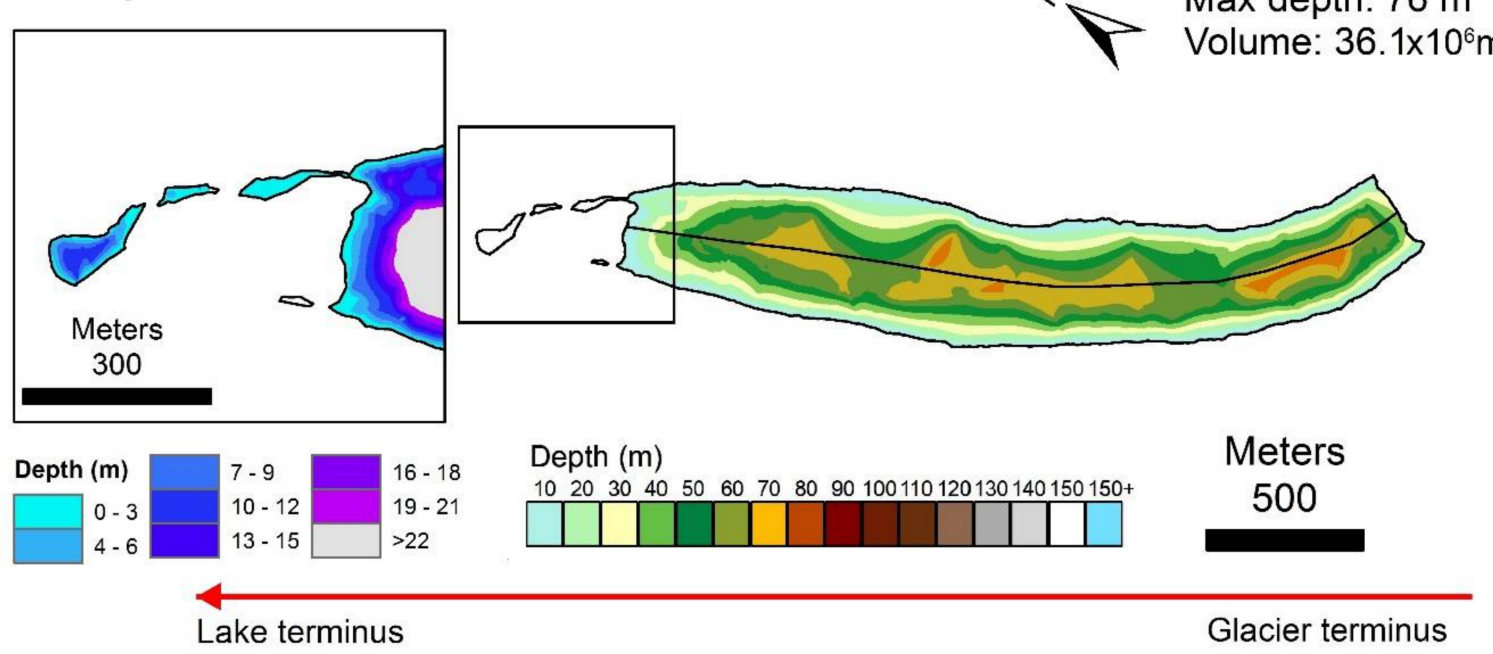

Figure 9. Smoothed bathymetric map of all three lakes. Inset shows the lake terminus area. 


\section{Discussion}

\subsection{Lake Evolution}

Ice-contact Himalayan lakes (proglacial and supraglacial) have expanded significantly in the last five decades. According to one estimate, between 1999-2005 moraine-dammed proglacial lake expansion contributed $83 \%$ of total glacial lake expansion in the Himalaya [78]. Our results indicate that the Everest and adjacent Makalu regions of the Himalaya are no different; the growth of both Imja and Lower Barun Lakes has accelerated since their formation in the 1950s and 1960s by the coalescence of small supraglacial lakes. For example, a 1967 Survey of India topographic map, which was based on 1958 vertical aerial photographs, does not indicate the presence of any moraine-dammed proglacial lake at the Lower Barun Glacier. The 1978 Schneider Map constructed from detailed fieldwork between 1955-1967 shows small lakes, but it is unclear when they were first observed during the 12 years of field work [79]. Thus, it is safe to assume early to mid-1960s as the formational beginning of Lower Barun Lakes.

Imja Lake, on the other hand, has a distinct growth pattern documented over the last six decades. The famous 1956 photograph taken either by Fritz Müller or Eric Schneider (Swiss Everest/Lhotse Expedition of 1956) shows seven supraglacial lakes (totaling $\left.0.03 \mathrm{~km}^{2}\right)[23,26,80]$. These lakes were also mapped on the 'Schneider Map', Khumbu Himal $(1: 50,000)$, which was based on terrestrial photogrammetry and field work conducted from 1956 to 1963 [81,82]. It is unclear whether the lakes of the 1950s were at that time in a quasi-steady-state, with annual or episodic seasonal filling and draining but no areal growth trend, or if they were already growing to form what would become Imja Lake. We take 1956 as an approximate zero-date for the initiation of Imja Lake growth, though we estimate an uncertainty of \pm 5 years. Further field surveys suggest that the area of the lake expanded from $0.40 \mathrm{~km}^{2}$ in 1984 to $0.60 \mathrm{~km}^{2}$ in 1992 [83]. Recently, several groups have measured the areal growth of Imja Lake using satellite and aerial photographs [75,84-87]. Reference [75] used Corona imagery to chart the growth of the lake from its inception; they found a set of lakes totaling $0.07 \mathrm{~km}^{2}$ in 1964. Imja Lake was first recognized in the terrestrial oblique photographs taken in 1975 by a Japanese glaciological research team (Japanese Glaciological Expedition of Nepal (GEN)) [88]. Lake expansion in the mid to late 1970s widened it from one lateral moraine to the other, after which its expansion occurred by lengthening as the glacier and the detached end moraine thinned and retreated from the lake's influence. Comparisons of repeat occupation photographs matching those of $1956[31,80]$ document the rapid evolution of the system, including the dramatic retreat and thinning of the glacier, the elongation of the lake, and variable melting and calving trends at the glacier and lake intersection $[5,31,84]$.

This timeline shows that, as expected, the lakes initially grew slowly, but as they increased in size, greater solar absorption by the larger lakes in the summer period caused thermal erosion, as well as enhanced ice calving and rapid melting at the glacier and lake interface [89]. However, ice melt at the calving front and the rate of calving are not solely dependent on the temperature of the proglacial water body; they can also be driven by free convection and subaqueous melting associated with upwelling and tidal action [64,90-92]. As Reference [92] pointed out, the thermal regime at the ice-contact water body has a crucial influence on calving. It appears that at Imja and Lower Barun Lakes it may have contributed to the higher retreat rates and increased calving more than at the relatively smaller and more shallow Thulagi Lake. Furthermore, glacial lakes with calving ice fronts are also linked with a relatively higher likelihood of failure [45,93-95], adding further to the hazard posed by both Imja and Lower Barun Lakes.

A recent study suggested that the Thulagi Glacier retreated from the lake to a land termination [96]. However, this land termination classification is unclear with our observations of a large calving event in 2018, where numerous tabular icebergs over $3 \mathrm{~m}$ high above water level-and perhaps extending $27 \mathrm{~m}$ deep-were discharged into the lake and floated away from the terminus (Figure S5). A salient point is that in 2013 we observed an ice buttress sloping steeply into the lake, and this buttress was 
covered by a thin sandy deltaic or debris-flow deposit from an englacial stream conduit; in 2018, the same area of the glacier front was marked by a cavernous structure through which probably the same englacial stream was discharging.

Overall, the glaciers in this region can be classified as floating/calving lake-terminating glaciers, non-floating (grounded) lake-terminating calving glaciers, and dry-land terminating glaciers. The high relief of the calving front at all three glaciers suggests that they are lake-terminating and calving but are not in flotation, except for near the lateral margins in the terminus areas. The flotation of the thinned margins might explain the tendency for lakes to protrude upvalley along the glacier margins (Figures S1 and S2).

\subsubsection{Distinct Thulagi Lake Evolution}

At Thulagi Lake, the long-term average growth rate slowed during the 1990s and almost ceased after 2000, contrasting with Imja and Lower Barun Lakes, which show accelerating growth rates. Although the moraine-dammed proglacial lake growth is slower compared to the other two lakes, in 1976 Thulagi was nearly $0.6 \mathrm{~km}^{2}$ in size, which was more than double the size of Imja Lake and almost six times the size of Lower Barun Lake at that time. It is difficult to confirm the inception of this lake, but a 1958 Survey of India topographic map shows a small lake with an area of $0.22 \mathrm{~km}^{2}$ [26].

The distinct pattern of lake evolution at Thulagi, relative to Imja and Lower Barun Lakes, could be due to a variety of reasons; we explore three aspects in this discussion which we deem to be key-diffuse skylight irradiance, glacier surface processes, and different ice-water contact areas. First, with respect to lake-water flow direction, Thulagi is oriented north-west, whereas Imja and Lower Barun Lakes are oriented west and east, respectively. Although lake and glacier terminus contacts for both Imja and Thulagi face west, Imja and Lower Barun Lakes and their associated glaciers' ablation zones are wide, and nearby ridges do not shield the entire proglacial lake and the glacier basin from solar radiation. However, Thulagi Lake is more shielded by extremely high ridges both to the north and south. Since the magnitude of radiation reaching the surface is controlled by the atmospheric constituents and topographic factors [97], the topographic shielding of skylight diffuse irradiance can be significant in deep valleys [98], such as at Thulagi. Of importance is the fact that the terminus region of all three glaciers receives more direct irradiance than the average values for the rest of the ablation area. Overall, Thulagi Lake is subject to higher topographic shielding compared to the other two lakes, which likely affects glacial melt and thus lake expansion. This distinction may also account for the fact that Thulagi Lake (along with its glacier) occurs $\sim 900 \mathrm{~m}$ below Imja Lake and $\sim 450 \mathrm{~m}$ below Lower Barun (and their glaciers). Overall, it is expected that glaciers at lower altitudes undergo recession more rapidly than those at higher altitudes, and that their proglacial lakes might be relatively unstable. However, once the moraine dams lose their ice, or become heavily vegetated, low-elevation lakes also may stabilize, which appears to be happening at Thulagi Lake (Figure S6).

The second reason for the relative stability of Thulagi Lake is the overall lack of glacier surface processes. We observed a relative absence of exposed ice cliffs and supraglacial lakes on Thulagi Glacier compared with Imja and Lower Barun Glaciers. These latter glacier surfaces contain numerous supraglacial lakes and ice cliffs which influence glacier dynamics and melting patterns, especially for larger supraglacial lakes as they are in the higher velocity zones [64]. For example, a high-resolution DigitalGlobe image available from 13 May 2016 shows more than 100 lakes and numerous ice cliffs on Imja and Lhotse Shar Glaciers and nearly 40 lakes on Lower Barun Glacier, which has $40 \%$ less debris cover in its ablation zone than Lhotse Shar Glacier. In stark contrast, a DigitalGlobe image of Thulagi Glacier from 4 May 2015 shows a lower number of ice cliffs relative to the Imja and Lower Barun Glaciers, and fewer than 10 supraglacial lakes. Both ice cliffs and supraglacial lakes are known to enhance melting [99-104]. As discussed earlier, these lakes, especially at the terminus, can coalesce and contribute to extending lake size and even calving [89].

Another compelling reason accounting for the different behaviors of the lake growth trends pertains to the ice/water contact areas and the intensity of the lake interaction with ice. Thulagi Lake 
is narrower than the other two lakes (Table 1), and due to their geometry, as the three lakes have expanded, Thulagi Lake has become even narrower at the calving front whereas Imja and Lower Barun Lakes have widened. Together with Imja's and Lower Barun's greater lake depths near the calving margin, those glaciers' lake/glacier contact areas are larger than Thulagi's. The volume of Thulagi Lake is less than half of Imja's and a third of Lower Barun's; it is really the smallest of the lakes, meaning that the area available to collect solar radiation and its capacity to retain solar energy is much less than the other two lakes. Thulagi Lake-compared to Imja and Lower Barun-also combines a smaller solar energy collecting lake area, a smaller lake volumetric capacity to retain that heat, and a smaller ice/water contact area into which lake-water can transmit solar heat to ice. This combination causes the lake-water interaction to be much weaker at Thulagi compared to the other two; Imja has the intermediate ice/water interactive capacity, with Lower Barun having the most. Furthermore, Thulagi's ice-water interaction, according to this simple parametric assessment, has decreased, whereas those of the other two have increased. We argue that fewer ice cliffs and supraglacial lakes (Figure 7), high topographical shielding, shallow lake depth at the interface of lake-water and glacier terminus, weak lake-water, and decreased ice-water interactions are some of the important factors contributing to the lower growth of Thulagi Lake.

Table 1. Some critical lake properties relevant to calving.

\begin{tabular}{cccccc}
\hline Lake & $\begin{array}{c}\text { Lake Width at } \\
\text { Calving Front }(\mathbf{m})\end{array}$ & $\begin{array}{c}\text { Lake Max } \\
\text { Depth } \mathbf{( m )}\end{array}$ & $\begin{array}{c}\text { Estimated Lake } \\
\text { Depth }(\mathbf{m})\end{array}$ & Lake Area $\left(\mathbf{m}^{\mathbf{2}}\right)$ & $\begin{array}{c}\text { Lake Volume } \\
\left(\mathbf{m}^{\mathbf{3}}\right)\end{array}$ \\
\hline Thulagi & 265 & 76 & up to 40 & $0.90 \times 10^{6}$ & $36.1 \times 10^{6}$ \\
Imja & 695 & 150 & up to 110 & $1.28 \times 10^{6}$ & $78.4 \times 10^{6}$ \\
Lower Barun & 770 & 205 & up to 110 & $1.80 \times 10^{6}$ & $112.3 \times 10^{6}$ \\
\hline
\end{tabular}

\subsubsection{Lake Evolution-Future Projections}

Figure 3 suggests that lake growth is variable over decadal timescales. For the purposes of future projections of glacial lake evolution, higher-order polynomials are far from ideal [65]. Therefore, we limited our forecast to eight years (until 2025; only 20\% spatial extrapolation based on $\sim 40$ years of annual retreat data generated in this study). The rapid evolutionary pattern of Lower Barun, when represented with both second- and third-order polynomial fits suggests a nearly 25\% expansion by 2025 . We therefore expect continued lake growth and calving-front retreat at Lower Barun until the total length of the lake approaches almost $5 \mathrm{~km}$ and the glacier terminus approaches the icefall. However, the actual growth trajectory depends on the bed profile and structure. Both exponential and polynomial lake growth put it a few decades away before this scenario will be reached. However, if this occurs, the lake will become increasingly hazardous because of the potential of icefall from a hanging Lower Barun Glacier terminus or rockslides into the lake from Chamlang ridge, which looms $>2000 \mathrm{~m}$ directly above the lake's south side. This type of hazard is highly dependent on the thickness of the unstable mass falling from the hanging portion of the glacier into the lake. Imja Lake's long-term growth has followed a slightly different pattern and, as a result, second- (14\% growth) and third-order polynomials (44\% growth) provide different projections up to 2025 . With the recent lake-lowering project and controlled lake outlet at Imja (discussed in Section 5.6), it appears that it will follow the lower end of our projection. However, further lake growth will completely detach Imja Glacier from Lhotse Shar Glacier, making Lhotse Shar Glacier the sole contributor to the main Imja Lake. Thulagi Lake, on the other hand, appears to be stable at this time, and it is unclear if this trend will continue and for how long.

Multiple studies have shown that mean annual temperatures have increased in high-altitude regions [105,106], but the trends in precipitation are not as clear in the Himalaya, partly because of the fluctuation in the Indian monsoon and Westerlies-driven precipitation. However, it is well established that the amount of precipitation, as well as its timing, phase, and distribution, does affect glacier responses on both annual and decadal timescales [107]. Temperature and precipitation have 
been linked with the observed negative glacier mass balance, rapid glacier recession, and increased melt runoff in the HMA region [1,11,108], in addition to changes in lake size. It is thought that there are broad west-to-east and north-to-south variations in climate change impacts occurring in the HMA region [109], so on this basis alone we expect inter-regional variability in glacier responses. Furthermore, along with this climate change variability, local orographic influences ought to be shifting as well, so the local changes in climate might not always track the regional and global average shifts. The subregional and local climate change variability coupled with differing glacier response timescales means that regionally across the Himalaya-Karakoram we ought to see heterogeneous glacier responses from one valley to another and between nearby glaciers, and we do $[11,14,16,17,110,111]$. It is thus not a given that glacial lake growth and behavioral dynamics will all be the same, as reflected by differing glacial lake growth patterns.

\subsection{Lake Bathymetry—Comparison with Previous Surveys}

Although no prior bathymetric survey of Lower Barun Lake exists, several surveys have been completed at Imja and Thulagi Lakes.

At Imja, our result indicates a significant change in lake volume in $2014\left(78.4 \times 10^{6} \mathrm{~m}^{3}\right)$ compared to a 2012 survey [87], which described Imja Lake as being $116 \mathrm{~m}$ deep, and containing $62 \times 10^{6} \mathrm{~m}^{3}$ of water. Key differences between our 2014 survey and the 2012 survey by Somos-Valenzuela is that the eastern third of the lake that was not surveyed in 2012 was assumed to become shallower, but our survey shows that it continues to deepen without any significant change in area. Extents of overlap between the two surveys show similar lake depths and bathymetric relief. Additionally, the 2012 survey estimated that the volume of a GLOF emanating from Imja could be 36 million $\mathrm{m}^{3}$, an increase from the previous estimate of 21 million $\mathrm{m}^{3}$ in 2002 [112]. Our 2014 survey only slightly increases this drainable volume, as most of our estimated volume change over that estimated by Reference [87] occurs at depths below the drainable level, i.e., elevation in front of the damming end moraine. However, for the upper eastern-most outlet lake, which is relevant from the lake outlet perspective, both 2012 and 2014 studies provided similar results. Previous bathymetric results show Imja Lake as having a volume of $28 \times 10^{6} \mathrm{~m}^{3}$ in 1992 [83] and a volume of $35.5 \times 10^{6} \mathrm{~m}^{3}$ and a 96.5-m maximum depth in 2009 [26]. These estimates indicate that Imja Lake is increasing in both total volume and depth; however, some of this apparent increase is likely due to improved measurements.

At Thulagi Lake, there are three known surveys prior to ours, and volumes reported are similar to our determination $\left(36.1 \times 10^{6} \mathrm{~m}^{3}\right)$. Reference [26] reported a lake volume of $35.3 \times 10^{6} \mathrm{~m}^{3}$ in 2009 and $31.75 \times 10^{6} \mathrm{~m}^{3}$ in 1995. The most recent survey was conducted by des Géorisques et Des Hommes $(\mathrm{GDH})$ in November 2013, with a lake volume estimate of $39 \times 10^{6} \mathrm{~m}^{3}$ and a maximum depth estimate of $82 \mathrm{~m}$ [113]. Although, the GDH website accessed on 9 May 2018 shows Thulagi Lake's volume to be $67.5 \times 10^{6} \mathrm{~m}^{3}$ and its depth to be $75 \mathrm{~m}$. Nonetheless, it is unclear how many sounding data points were acquired during these surveys. ICIMOD's report shows one longitudinal depth profile, but no vessel tracks to indicate the sounding density, whereas the GDH report shows modeled 2013 bathymetry and a supposed superimposed vessel track from a 2009 ICIMOD survey, and it is clear that those survey points are not continuous. It must be noted, however, that the lake bottom profiles showing undulating bed topography in each of these surveys are similar to ours. Overall, our lake evolution analysis and bathymetric results from 2017, compared with ICIMOD's survey from 2009, suggests very little to almost no change in Thulagi Lake's depth or volume.

\subsection{Glacier Dynamic Evolution}

Imja, Lhotse Shar, Lower Braun, and Thulagi Glaciers exhibit highly variable spatiotemporal patterns with respect to surface flow speeds. Our discussion here pertains only to the areas below the icefalls and the terminus region. However, it is not straightforward to compare the terminus region surface velocity at the lake terminating glacier because this dynamic zone was not located at the same place in previous time periods. A notable feature of the glacier system in these regions is that flow 
diminishes beneath the icefall to the terminus [71,114,115]. As expected, Lhotse Shar and Thulagi Glaciers have verged toward flow stagnation during the recent time period, but Lower Barun Glacier shows an acceleration in the terminal $1000 \mathrm{~m}$ in the same time period. This is not the behavior that would occur with dry land terminating glaciers, and so it would appear to be related to the deep lake calving property of Lower Barun Glacier, perhaps caused by a reduction in basal shear stress due to the partial buoyancy of the glacier. As discussed earlier, Lower Barun Lake also shows 50\% faster growth over the long-term average annual growth rate during last three years, thus showing a potential correlation between calving, high ice velocity, and rapid lake growth.

Lower Barun Glacier has a flow pattern that approaches plug flow, where cross profiles of flow speed show almost uniform movement indicative of significant basal sliding. Lhotse Shar and Thulagi Glaciers each exhibit some areas where the flow is similar to that of Lower Barun Glacier, i.e., verging toward plug flow, but overall the flow speed is distinctly a maximum near the centerline and declines toward the margins, thus resembling bilaterally symmetric flow that is likely indicative of internal ice deformation. The flow in general for the three glaciers beneath the icefalls was observed to be episodic.

\subsection{State and Dynamics of the Moraines and Glacier Thinning}

Several geochronological studies in the Imja and Everest regions have been carried out, resulting in an extensive and improved chronological record using ${ }^{10} \mathrm{Be}$ terrestrial cosmogenic nuclide (TCN) ages [116,117]. However, little research has been undertaken in the Lower Barun and Thulagi basins. Here we discuss some geochronological dates from the Imja basin and develop possible trends which may be applicable to other basins. The deposition of the youngest lateral moraines in the Everest area (Lobouche stage and historical) and the most recent glacial advance recorded by the moraines occurred somewhere around 400-1000 ka [117]. This period and the warming associated with the termination of the Little Ice Age occurred long before the period of anthropogenic warming began. Glacier thinning was already underway by the early 20th century, and that has to be related to the termination of the Little Ice Age and completely unrelated to anthropogenic warming. The period of lake initiation in the 1960s and 1970s began after anthropogenic warming had initiated, but was not yet a major climatic shift. The glacier thinning that set the stage for lake development has a longer history and more complicated attributions including lake development, glacier detachment, as well as glacier thinning and retreat. The 1962 Corona image shows that Amphulapche Glacier may have already detached or was in the process of detachment from the main Imja Glacier system [86]. Indeed, there likely has been a sequence of tributary detachments and breakup of many glaciers across the Himalayan region and elsewhere [118-120]. From the early 20th century, the main dynamical actions at Imja started with the detachment from Lhotse Glacier, then the detachment of Amphulapche Glacier and the formation of Imja Lake, and most recently the rapid growth of Imja Lake and the slowing and continued thinning of Imja and Lhotse Shar Glaciers. Based on moraine evidence and our bathymetric mapping, the lake area close to the present terminus of Imja Glacier and along the lake centerline was likely occupied by ice about $300 \mathrm{~m}$ thick a century ago [31].

Whereas the early glacier thinning and formation of supraglacial ponds was not likely controlled by anthropogenic warming, recent rapid climatic warming — known to be related to anthropogenic greenhouse gases and global warming-probably has contributed to the recent decades of lake growth; however, anthropogenic and natural components of climate change (including post-Little Ice Age warming) are perhaps intractably intertwined.

The geomorphological evidence we have discussed shows that glacier thinning has a long history, but has continued and increased in the modern era due to lake-glacier interactions in addition to the termini occurring within zones of maximum downward radiant flux. Direct measurements of the thinning of the ice-cored end moraines of all three glaciers gave an average of -0.3 to $-0.4 \mathrm{~m}$ /year. Higher rates were observed around small lakes on the end moraine, suggesting that thermal undercutting by lake and thermokarst development (Figure 6 and Figures S1-S3) may enhance rapid changes at these features, potentially contributing to the further instability of 
the lake. References $[85,121]$ observed thinning even on the relict ice-cored moraine located below Imja Lake, providing further evidence of instability within this zone. At the thinning rates that we have observed, it would take many decades to transform a parabolic glacier profile into a form where low- to mid-glacier gradients produce significant supraglacial lakes. The actual thinning rates averaged over the glacier termini are several times greater than the rate observed at the end moraine (highest at Thulagi and lowest at Imja), corresponding to areas of thick debris cover. In the absence of more comprehensive high-resolution DEM data for various periods, we do not suggest that the thinning rate for other periods was constant or averaged at this rate for the ice-cored end moraine and glacier terminus.

The continuous glacier downwasting at all three glaciers and elsewhere in the Himalayan region is leading to the debuttressing of surrounding rock and debris slopes and it is predicted that this will increase debris fluxes to glacier surfaces $[109,122]$. Depending on the debris depth, the added supraglacial debris load will variably protect the glacier from high ablation where the debris cover is sufficiently thick, and increase ablation where the debris cover is thinner [123,124]. Over time, sediment transport due to increased meltwater production will decrease the depth of debris loads thereby increasing ablation, which collectively increases lake formation potential and therefore hazards $[11,103,125,126]$. Furthermore, an increase in the surface load may influence the englacial and basal hydrological conditions that can lead to increased outburst flooding from subglacial water stores or produce increased basal sliding velocities.

\subsection{Lake Stability and Hazards Associated with GLOFs}

Some scientific disagreement exists about the types of triggers and degree of hazards and risks due to GLOFs that they represent, but not all hazards are similar. Identifying the possible triggers at each lake, the range of associated hazards, and the percentage and rates of water spilling out of the lakes is beyond the scope of this paper. In general, potential failures and prospects for damaging GLOFs is dependent upon on the volume of lake-water; the lakes' topographic settings and unstable surroundings; the pattern of lake evolution; the type and rapidity of breach and seepage coming through the unconsolidated (or poorly consolidated) end moraine, indicating the piping of water and instability of the moraine; and of course the vulnerabilities downstream from the lakes $[17,30,94,127,128]$.

The three studied glaciers-Lower Barun and Imja-Lhotse Shar Glaciers more so than Thulagi-and many others in the region have numerous supraglacial lakes with a potential to directly produce small GLOFs $[129,130]$. Additionally, another possibility could be the failure of some combinations of supraglacial, englacial, and subglacial conduits leading to the sudden increase in hydrostatic pressure in the existing moraine-dammed proglacial lake and a resultant GLOF [131]. One recent example includes the sudden draining of small supraglacial lake on Lhotse Glacier leading to a flood surge of $6 \mathrm{~m}$, an estimated instantaneous discharge of $1500 \mathrm{~m}^{3} / \mathrm{s}$, and minor damage downstream in Chukung village [132].

Rockfalls, landslides, and avalanches of large magnitude that may occur by moraine collapse or bedrock failures from steep, high slopes are common in this region [133] and can produce GLOFs if the mobilized mass reaches the lake with high mass and energy and a short duration of infall into the lakes. A very worrisome aspect in the studied glaciers is the presence of Upper Barun Lake (Figure S7), from which outbursts would spill and overfill Lower Barun Lake possibly by several meters-enough to trigger a much larger GLOF.

Reference [37] argued that recent changes at Imja suggest that a likely trigger could be the self-destructive moraine failure. Although engineered lake-lowering has reduced the drainable volume, the external triggers remain the same, if somewhat reduced in magnitude and effectiveness as triggers. Thulagi Lake might be the least hazardous (but not completely safe) of the three lakes considered in this paper. Thulagi Lake's end moraine dam is moderately vegetated with shrubs (Figure S6), which indicates a degree of stability of the moraine and a reduced geomorphological 
process rate $[132,134,135]$, so massive piping failures are possibly less likely than with the other two glacier systems. Consistent with the vegetation state, Figure 5 shows that, of the three lakes' moraine dams, Thulagi's is downwasting the most slowly. However, the presence of ponds and undulating relief suggests that there is some thermokarstic development-but not very rapid. For all of these lakes, overfill by mass movements or small GLOFs into the main lakes remains a potent threat.

\subsection{Engineered Lowering of Imja Lake and Prognosis for Other Lakes}

Imja Lake's level had an engineered reduction by $3.4 \mathrm{~m}$ in 2016 (Figure S8) [37], which reduced the drainable volume by about $10 \%$. The readily drainable volume of a glacial lake is that resting above the level of the valley below the end moraine dam (including overfill volume additions of water or debris). Any additional volume drainage would have to be by an impulse wave. The lake reduction also lowered the peak hydraulic pressure on the moraine at the lowest drain point by $10 \%$ and increased the freeboard operative against displacement waves. Hence, the chances of a glacial lake outburst have been reduced, as well as the magnitude of a potential GLOF should one occur. As the lake area is expected to eventually resume growth after a possible period of stabilization due to the lake-lowering, the drainable volume will resume its growth, although the hydraulic pressure will remain at the reduced level. If the lake continues its growth pattern as highlighted in this study, further reductions in lake level may be necessary.

The Imja Lake-lowering project provides lessons for other hazardous high mountain locations in Nepal and elsewhere. Although the lowering was successful, a larger and more lasting reduction of the GLOF hazard awaits the implementation of more advanced technologies that may lower these lake levels by $10 \mathrm{~m}$ or more. Furthermore, we recommend near-term hazard mitigating intervention at Lower Barun Lake, especially considering its rapid growth and upvalley deepening profile, and the existence of Upper Barun Lake as a dangerous part of the system, whereby a hazardous chain of processes could easily elapse. We also suggest including local community and other stakeholders in the mitigation discussion, especially because community observations and experience with past GLOF events in the region can provide important information for researchers and stakeholders, as well as lend critical community response and input into issues of local and regional planning [136].

\section{Concluding Remarks}

Detailed field surveys and Landsat satellite image and DEM analyses were used to document and evaluate the evolution of Imja, Lower Barun, and Thulagi moraine-dammed proglacial lakes in the Nepal Himalaya. All three lakes have expanded from initial clusters of small supraglacial lakes in the 1950s /1960s to large hazardous, ice-cored, moraine-dammed proglacial lakes with water volumes of $78.4 \times 10^{6} \mathrm{~m}^{3}, 112.3 \times 10^{6} \mathrm{~m}^{3}$, and $36.1 \times 10^{6} \mathrm{~m}^{3}$, respectively. The growth rates of the three lakes follow different trajectories, an observation attributed to differing ice/water contact areas and other characteristics (e.g., geometry) of the glaciers and lakes and the surrounding topography. These lakes currently drain through relatively stable, boulder-armored channels, but the condition of these channels is different at each location. Relatively high surface irradiance over the lower portion of each glacier will ensure that meltwater production will remain high and promote future lake enlargement. Furthermore, numerous studies have concluded that these glaciers are responding to climate change-both ongoing anthropogenic change and natural climate change stemming from the end of the Little Ice Age. This will lead to further glacier retreat, downwasting, lake formation, and expansion. Additionally, coupled system responses-including potential for mass movements into each of the lakes-will continue and contribute to increasing high hazard potential in the future.

Lower Barun Lake is one of the largest, deepest, and most rapidly growing lakes in Nepal, and appears to have a relatively unstable outlet channel and numerous hazard triggers around the lake. The growing size of the lake $\left(\sim 0.5 \mathrm{~km}^{2}\right.$ in the last decade) will likely increase the load on the moraine, reducing its ability to contain the impoundment, hence increasing the probability of rapid lake drainage. Whether a lake drainage produces a major GLOF would depend on the type of breach. 
We recommend continuous monitoring and possible lake-lowering intervention after further detailed surveys. Imja Lake has recently undergone engineered channelized drainage, further stabilizing its outlet, while a relatively stable, vegetated end moraine surrounds the Thulagi Lake outlet. However, Thulagi's outlet is extremely precarious, as a small lake level rise of a couple meters could suddenly erode and enlarge the outlet.

Supplementary Materials: The following are available online at http:/ / www.mdpi.com/2072-4292/10/5/798/s1, Figure S1: A color composite of a time series of Landsat satellite images showing the growth of Imja Lake from 1975-2016, Figure S2: A color composite of a time series of Landsat satellite images showing the growth of Lower Barun Lake from 1975-2016, Figure S3: A color composite of a time series of Landsat satellite images showing the growth of Thulagi Lake from 1973-2016, Figure S4: Centerline lake transect, Figure S5: Icebergs in Thulagi Lake. Photographs by J. Kargel, 30 October 2017, Figure S6: (a,b) Field photographs showing vegetation on an ice-cored end moraine. $(\mathrm{c}, \mathrm{d})$ Bird's eye view of Thulagi Lake where a dark-colored end moraine is reflecting some of the vegetation growth. Photographs by J. Kargel, 3 May 2013, Figure S7: Upper Barun Lake and possible flood route in case of an outburst, Figure S8: Imja Lake-lowering project (a-d) and part of a warning siren network (e), Table S1: List of Landsat satellite imageries used in this study.

Author Contributions: U.K.H., J.S.K. and G.J.L. conceived the study and collected field data. U.K.H., J.S.K. and D.H.S. structured and drafted the manuscript with significant help from all other authors. Specifically, K.S. and U.K.H. processed ice velocity data, D.H.S. mapped lake extents from satellite data, C.S.W. collected Thulagi bathymetry data, D.S. generated DEMs, S.H. provided valuable climate perspective, K.T.M. helped in assessing hazards, and D.R. supported field experiments.

Acknowledgments: This work was supported by the National Aeronautics and Space Administration (NASA) High Mountain Asia grant NNX16AQ62G, SERVIR Applied Science Team grant NNX12AO96G, Interdisciplinary Research in Earth Science grant NNX17AL80G, and United Nations Development Program's Imja Lake-Lowering project. D. Shean was supported by the NASA cryosphere program (award no. NNX16AQ88G). The authors thank Wojciech Marcinek, Daniel Hicks, Adil Tahir, and Charles Howard for designing and building the sonar device ('BathyBot') adapted for the Thulagi bathymetry survey within the School of Mechanical Engineering at the University of Leeds, and Robert Richardson and Shaun Whitehead for their guidance on the project.

Conflicts of Interest: The authors declare no conflict of interest.

\section{References}

1. Kraaijenbrink, P.D.A.; Bierkens, M.F.P.; Lutz, A.F.; Immerzeel, W.W. Impact of a global temperature rise of 1.5 degrees celsius on asia's glaciers. Nature 2017, 549, 257. [CrossRef] [PubMed]

2. Roe, G.H.; Baker, M.B.; Herla, F. Centennial glacier retreat as categorical evidence of regional climate change. Nat. Geosci. 2017, 10, 95. [CrossRef]

3. Shugar, D.H.; Clague, J.J.; Best, J.L.; Schoof, C.; Willis, M.J.; Copland, L.; Roe, G.H. River piracy and drainage basin reorganization led by climate-driven glacier retreat. Nat. Geosci. 2017, 10, 370. [CrossRef]

4. Kargel, J.S.; Leonard, G.J.; Bishop, M.P.; Kääb, A.; Raup, B.H. Global Land Ice Measurements from Space; Springer: Heidelberg, Germany, 2014.

5. Ives, J.D.; Shrestha, R.B.; Mool, P.K. Formation of Glacial Lakes in the Hindu Kush-Himalayas and Glof Risk Assessment; ICIMOD: Kathmandu, Nepal, 2010.

6. Cruz, R.V.; Harasawa, H.; Lal, M.; Wu, S.; Anokhin, Y.; Punsalmaa, B.; Honda, Y.; Jafari, M.; Li, C.; Huu Ninh, N. Asia. In Climate Change 2007: Impacts, Adaptation and Vulnerability. Contribution of Working Group II to the Fourth Assessment Report of the Intergovernmental Panel on Climate Change'; Parry, M.L., Canziani, O.F., Palutikof, J.P., van der Linden, P.J., Hanson, C.E., Eds.; Cambridge University Press: Cambridge, UK; pp. 469-506.

7. Schiermeier, Q. Glacier Estimate is on Thin Ice; Nature Publishing Group: New York, NY, USA, 2010.

8. Cogley, J.G. Himalayan glaciers in 2010 and 2035. In Encyclopedia of Snow, Ice and Glaciers; Springer: Heidelberg, Germany, 2011; pp. 520-523.

9. Nüsser, M.; Baghel, R. The emergence of the cryoscape: Contested narratives of himalayan glacier dynamics and climate change. Environ. Clim. Chang. South Southeast Asia 2014, 2, 138-156.

10. Immerzeel, W.W.; Van Beek, L.P.H.; Bierkens, M.F.P. Climate change will affect the asian water towers. Science 2010, 328, 1382-1385. [CrossRef] [PubMed]

11. Bolch, T.; Kulkarni, A.; Kääb, A.; Huggel, C.; Paul, F.; Cogley, J.G.; Frey, H.; Kargel, J.S.; Fujita, K.; Scheel, M. The state and fate of himalayan glaciers. Science 2012, 336, 310-314. [CrossRef] [PubMed] 
12. Bajracharya, S.R.; Maharjan, S.B.; Shrestha, F.; Bajracharya, O.R.; Baidya, S. Glacier Status in Nepal and Decadal Change from 1980 to 2010 Based on Landsat Data; International Centre for Integrated Mountain Development: Kathmandu, Nepal, 2014.

13. Brun, F.; Berthier, E.; Wagnon, P.; Kääb, A.; Treichler, D. A spatially resolved estimate of high mountain asia glacier mass balances from 2000 to 2016. Nat. Geosci. 2017, 10, 668-673. [CrossRef] [PubMed]

14. Azam, M.F.; Wagnon, P.; Berthier, E.; Vincent, C.; Fujita, K.; Kargel, J.S. Review of the status and mass changes of himalayan-karakoram glaciers. J. Glaciol. 2018, 64, 61-74. [CrossRef]

15. Cogley, J.G. Climate science: Himalayan glaciers in the balance. Nature 2012, 488, 468. [CrossRef] [PubMed]

16. Fujita, K.; Nuimura, T. Spatially heterogeneous wastage of himalayan glaciers. Proc. Natl. Acad. Sci. USA 2011, 108, 14011-14014. [CrossRef] [PubMed]

17. Kargel, J.S.; Cogley, J.G.; Leonard, G.J.; Haritashya, U.; Byers, A. Himalayan glaciers: The big picture is a montage. Proc. Natl. Acad. Sci. USA 2011, 108, 14709-14710. [CrossRef] [PubMed]

18. Carrivick, J.L.; Tweed, F.S. Proglacial lakes: Character, behaviour and geological importance. Q. Sci. Rev. 2013, 78, 34-52. [CrossRef]

19. Wang, X.; Ding, Y.; Liu, S.; Jiang, L.; Wu, K.; Jiang, Z.; Guo, W. Changes of glacial lakes and implications in tian shan, central asia, based on remote sensing data from 1990 to 2010. Environ. Res. Lett. 2013, 8, 044052. [CrossRef]

20. Truffer, M.; Motyka, R.J. Where glaciers meet water: Subaqueous melt and its relevance to glaciers in various settings. Rev. Geophys. 2016, 54, 220-239. [CrossRef]

21. Linsbauer, A.; Frey, H.; Haeberli, W.; Machguth, H.; Azam, M.F.; Allen, S. Modelling glacier-bed overdeepenings and possible future lakes for the glaciers in the himalaya-Karakoram region. Ann. Glaciol. 2016, 57, 119-130. [CrossRef]

22. Chalise, S.R.; Shrestha, M.L.; Bajracharya, O.R.; Shrestha, A.B. Climate change impacts on glacial lakes and glacierized basins in Nepal and implications for water resources. In Climate Variability and Change. Hydrological Impacts; IAHS Publications: Hamburg, Germany, 2006; Volume 308, pp. 460-465.

23. Watanabe, T.; Lamsal, D.; Ives, J.D. Evaluating the growth characteristics of a glacial lake and its degree of danger of outburst flooding: Imja Glacier, Khumbu Himal, Nepal. Norsk Geografisk Tidsskrift 2009, 63, 255-267. [CrossRef]

24. Bajracharya, S.R.; Mool, P. Glaciers, glacial lakes and glacial lake outburst floods in the mount everest region, Nepal. Ann. Glaciol. 2009, 50, 81-86. [CrossRef]

25. Komori, J. Recent expansions of glacial lakes in the bhutan himalayas. Q. Int. 2008, 184, 177-186. [CrossRef]

26. International Centre for Integrated Mountain Development; Mool, P. Glacial Lakes and Glacial Lake Outburst Floods in Nepal; International Centre for Integrated Mountain Development: Kathmandu, Nepal, 2011.

27. Yamada, T.; Sharma, C.K. Glacier lakes and outburst floods in the Nepal Himalaya. In Snow and Glacier Hydrology; IAHS Publications: Hamburg, Germany, 1993; Volume 218, pp. 319-330.

28. Harrison, S.; Kargel, J.S.; Huggel, C.; Reynolds, J.; Shugar, D.H.; Betts, R.A.; Emmer, A.; Glasser, N.; Haritashya, U.K.; Klimeš, J.; et al. Climate change and the global pattern of moraine-dammed glacial lake outburst floods. Cryosphere 2018, 12, 1195-1209. [CrossRef]

29. Rounce, D.R.; Watson, C.S.; McKinney, D.C. Identification of hazard and risk for glacial lakes in the Nepal Himalaya using satellite imagery from 2000-2015. Remote Sens. 2017, 9, 654. [CrossRef]

30. Rounce, D.R.; McKinney, D.C.; Lala, J.M.; Byers, A.C.; Watson, C.S. A new remote hazard and risk assessment framework for glacial lakes in the Nepal Himalaya. Hydrol. Earth Syst. Sci. 2016, 20, 3455. [CrossRef]

31. Kargel, J.S.; Haritashya, U.K.; Leonard, G.J.; Regmi, D.; Chand, M.; Joshi, S.; Mool, P. The Community Based Flood and Glacial Lake Outburst Risk Reduction Project (CFGORRP). 2015. Available online: http: / / cfgorrp.dhm.gov.np/accomplishments/undp-imja-final-report/ (accessed on 21 May 2018).

32. Benn, D.I.; Bolch, T.; Hands, K.; Gulley, J.; Luckman, A.; Nicholson, L.I.; Quincey, D.; Thompson, S.; Toumi, R.; Wiseman, S. Response of debris-covered glaciers in the mount everest region to recent warming, and implications for outburst flood hazards. Earth-Sci. Rev. 2012, 114, 156-174. [CrossRef]

33. Costa, J.E.; Schuster, R.L. The formation and failure of natural dams. Geol. Soc. Am. Bull. 1988, 100, $1054-1068$. [CrossRef]

34. Clague, J.J.; Evans, S.G. A review of catastrophic drainage of moraine-dammed lakes in british columbia. Q. Sci. Rev. 2000, 19, 1763-1783. [CrossRef] 
35. Rana, B.; Shrestha, A.B.; Reynolds, J.M.; Aryal, R. Hazard assessment of the tsho rolpa glacier lake and ongoing. J. Nepal Geol. Soc. 2000, 22, 563-570.

36. Emmer, A.; Vilímek, V.; Zapata, M.L. Hazard mitigation of glacial lake outburst floods in the cordillera blanca (Peru): The effectiveness of remedial works. J. Flood Risk Manag. 2018, 11, S489-S501. [CrossRef]

37. Cuellar, A.D.; McKinney, D.C. Decision-making methodology for risk management applied to Imja Lake in Nepal. Water 2017, 9, 591. [CrossRef]

38. Watanbe, T.; Rothacher, D. The 1994 Lugge Tsho glacial lake outburst flood, Bhutan Himalaya. Mt. Res. Dev. 1996, 16, 77-81. [CrossRef]

39. Haeberli, W.; Kääb, A.; Mühll, D.V.; Teysseire, P. Prevention of outburst floods from periglacial lakes at grubengletscher, valais, swiss alps. J. Glaciol. 2001, 47, 111-122. [CrossRef]

40. Huggel, C.; Kääb, A.; Haeberli, W.; Teysseire, P.; Paul, F. Remote sensing based assessment of hazards from glacier lake outbursts: A case study in the swiss alps. Can. Geotech. J. 2002, 39, 316-330. [CrossRef]

41. Kershaw, J.A.; Clague, J.J.; Evans, S.G. Geomorphic and sedimentological signature of a two-phase outburst flood from moraine-dammed Queen Bess Lake, British Columbia, Canada. Earth Surf. Process. Landf. 2005, 30, 1-25. [CrossRef]

42. Harrison, S.; Glasser, N.; Winchester, V.; Haresign, E.; Warren, C.; Jansson, K. A glacial lake outburst flood associated with recent mountain glacier retreat, patagonian andes. Holocene 2006, 16, 611-620. [CrossRef]

43. Hegglin, E.; Huggel, C. An integrated assessment of vulnerability to glacial hazards: A case study in the cordillera blanca, peru. Mt. Res. Dev. 2008, 28, 299-309. [CrossRef]

44. Dussaillant, A.; Benito, G.; Buytaert, W.; Carling, P.; Meier, C.; Espinoza, F. Repeated glacial-lake outburst floods in Patagonia: An increasing hazard? Nat. Hazards 2010, 54, 469-481. [CrossRef]

45. Mergili, M.; Schneider, J.F. Regional-scale analysis of lake outburst hazards in the southwestern Pamir, Tajikistan, based on remote sensing and GIS. Nat. Hazards Earth Syst. Sci. 2011, 11, 1447-1462. [CrossRef]

46. Schneider, D.; Huggel, C.; Cochachin, A.; Guillén, S.; García, J. Mapping hazards from glacier lake outburst floods based on modelling of process cascades at lake 513, Carhuaz, Peru. Adv. Geosci. 2014, 35, 145. [CrossRef]

47. Iribarren Anacona, P.; Mackintosh, A.; Norton, K.P. Hazardous processes and events from glacier and permafrost areas: Lessons from the chilean and argentinean andes. Earth Surf. Process. Landf. 2015, 40, $2-21$. [CrossRef]

48. Shijin, W.; Dahe, Q.; Cunde, X. Moraine-dammed lake distribution and outburst flood risk in the chinese himalaya. J. Glaciol. 2015, 61, 115-126. [CrossRef]

49. Reynolds, J.M. Assessing glacial hazards for hydro development in the Himalayas, Hindu Kush and Karakoram. Int. J. Hydropower Dams 2014, 21, 60-65.

50. Zaginaev, V.; Ballesteros-Cánovas, J.A.; Erokhin, S.; Matov, E.; Petrakov, D.; Stoffel, M. Reconstruction of glacial lake outburst floods in northern tien shan: Implications for hazard assessment. Geomorphology 2016, 269, 75-84. [CrossRef]

51. Carrivick, J.L.; Tweed, F.S. A global assessment of the societal impacts of glacier outburst floods. Glob. Planet. Chang. 2016, 144, 1-16. [CrossRef]

52. Richardson, S.D.; Reynolds, J.M. An overview of glacial hazards in the himalayas. Q. Int. 2000, 65, 31-47. [CrossRef]

53. Schwanghart, W.; Worni, R.; Huggel, C.; Stoffel, M.; Korup, O. Uncertainty in the himalayan energy-water nexus: Estimating regional exposure to glacial lake outburst floods. Environ. Res. Lett. 2016, 11, 074005. [CrossRef]

54. Konz, M.; Braun, L.; Grabs, W.; Shrestha, A.; Uhlenbrook, S. Runoff from Nepalese Headwater Catchments: Measurements and Modelling; Unesco International Hydrological Programme: Paris, France, 2006.

55. Hambrey, M.J.; Quincey, D.J.; Glasser, N.F.; Reynolds, J.M.; Richardson, S.J.; Clemmens, S. Sedimentological, geomorphological and dynamic context of debris-mantled glaciers, mount everest (Sagarmatha) region, Nepal. Q. Sci. Rev. 2008, 27, 2361-2389. [CrossRef]

56. Krumwiede, B.S.; Kamp, U.; Leonard, G.J.; Kargel, J.S.; Dashtseren, A.; Walther, M. Recent glacier changes in the mongolian altai mountains: Case studies from munkh khairkhan and tavan bogd. In Global Land Ice Measurements from Space; Springer: Heidelberg, Germany, 2014; pp. 481-508.

57. Shean, D.E.; Alexandrov, O.; Moratto, Z.M.; Smith, B.E.; Joughin, I.R.; Porter, C.; Morin, P. An automated, open-source pipeline for mass production of digital elevation models (DEMS) from very-high-resolution commercial stereo satellite imagery. J. Photogram. Remote Sens. 2016, 116, 101-117. [CrossRef] 
58. Shean, D.E. High Mountain Asia 8-Meter Dems Derived from Along-Track Optical Imagery, 1st ed.; NASA National Snow and Ice Data Center Distributed Active Archive Center: Boulder, CO, USA, 2017.

59. Shean, D.E. High Mountain Asia 8-Meter Dems Derived from Cross-Track Optical Imagery, 1st ed.; NASA National Snow and Ice Data Center Distributed Active Archive Center: Boulder, CO, USA, 2017.

60. Hansen, M.C.; Potapov, P.V.; Moore, R.; Hancher, M.; Turubanova, S.; Tyukavina, A.; Thau, D.; Stehman, S.V.; Goetz, S.J.; Loveland, T.R. High-resolution global maps of 21st-century forest cover change. Science 2013, 342, 850-853. [CrossRef] [PubMed]

61. Höhle, J.; Höhle, M. Accuracy assessment of digital elevation models by means of robust statistical methods. J. Photogram. Remote Sens. 2009, 64, 398-406. [CrossRef]

62. Zakšek, K.; Oštir, K.; Kokalj, Ž. Sky-view factor as a relief visualization technique. Remote Sens. 2011, 3, 398-415. [CrossRef]

63. Richter, R.; Schläpfer, D. Atmospheric/Topographic Correction for Satellite Imagery; DLR Report DLR-IB; DLR: Oberpfaffenhofen, Germany, 2005; p. 565-01.

64. Röhl, K. Characteristics and evolution of supraglacial ponds on debris-covered tasman glacier, new zealand. J. Glaciol. 2008, 54, 867-880. [CrossRef]

65. Chinn, T.J.; Kargel, J.S.; Leonard, G.J.; Haritashya, U.K.; Pleasants, M. New Zealand's glaciers. In Global Land Ice Measurements from Space; Springer: Heidelberg, Germany, 2014; pp. 675-715.

66. Leprince, S.; Ayoub, F.; Klinger, Y.; Avouac, J.-P. Co-registration of optically sensed images and correlation (COSI-Corr): An operational methodology for ground deformation measurements. In Proceedings of the 2007 International Geoscience and Remote Sensing Symposium, Barcelona, Spain, 23-27 July 2007; pp. 1943-1946.

67. Scherler, D.; Leprince, S.; Strecker, M.R. Glacier-surface velocities in alpine terrain from optical satellite imagery-Accuracy improvement and quality assessment. Remote Sens. Environ. 2008, 112, 3806-3819. [CrossRef]

68. Sam, L.; Bhardwaj, A.; Singh, S.; Kumar, R. Remote sensing flow velocity of debris-covered glaciers using landsat 8 data. Prog. Phys. Geogr. 2016, 40, 305-321. [CrossRef]

69. Gibson, M.J.; Glasser, N.F.; Quincey, D.J.; Mayer, C.; Rowan, A.V.; Irvine-Fynn, T.D.L. Temporal variations in supraglacial debris distribution on baltoro glacier, karakoram between 2001 and 2012. Geomorphology 2017, 295, 572-585. [CrossRef]

70. Ragettli, S.; Bolch, T.; Pellicciotti, F. Heterogeneous glacier thinning patterns over the last 40 years in langtang himal. Cryosphere 2016, 10, 2075-2097. [CrossRef]

71. Haritashya, U.K.; Pleasants, M.S.; Copland, L. Assessment of the evolution in velocity of two debris-covered valley glaciers in Nepal and New Zealand. Geogr. Ann. Ser. A Phys. Geogr. 2015, 97, 737-751. [CrossRef]

72. Thompson, S.; Benn, D.I.; Mertes, J.; Luckman, A. Stagnation and mass loss on a himalayan debris-covered glacier: Processes, patterns and rates. J. Glaciol. 2016, 62, 467-485. [CrossRef]

73. Watson, C.S.; Quincey, D.J.; Carrivick, J.L.; Smith, M.W.; Rowan, A.V.; Richardson, R. Heterogeneous water storage and thermal regime of supraglacial ponds on debris-covered glaciers. Earth Surf. Process. Landf. 2018, 43, 229-241. [CrossRef]

74. International Hydrographic Organization (IHO). IHO Standards for Hydrographic Surveys; IHO: Monaco, 2008 ; p. 36.

75. Lamsal, D.; Sawagaki, T.; Watanabe, T. Digital terrain modelling using corona and alos prism data to investigate the distal part of Imja Glacier, Khumbu Himal, Nepal. J. Mt. Sci. 2011, 8, 390-402. [CrossRef]

76. Hanisch, J.; Delisle, G.; Pokhrel, A.P.; Dixit, A.M.; Reynolds, J.M.; Grabs, W.E. The Thulagi Glacier Lake, Manaslu Himal, Nepal-hazard assessment of a potential outburst. In Proceedings of the 8th International Conference of the IAEG, Vancouver, BC, Canada, 21-25 September 1998; pp. 2209-2215.

77. Somos-Valenzuela, M.; McKinney, D.C.; Byers, A.C.; Voss, K.; Moss, J.; McKinney, J.C. Ground Penetrating Radar Survey for Risk Reduction at Imja Lake, Nepal; Center for Research in Water Resources, University of Texas at Austin: Austin, TX, USA, 2012.

78. Nie, Y.; Sheng, Y.; Liu, Q.; Liu, L.; Liu, S.; Zhang, Y.; Song, C. A regional-scale assessment of himalayan glacial lake changes using satellite observations from 1990 to 2015. Remote Sens. Environ. 2017, 189, 1-13. [CrossRef]

79. WECS. Preliminary Report on the First Field Investigation on the Lower Barun Glacier Lake; WECS: Kathmandu, Nepal, 1993. 
80. Byers, A.C. An assessment of contemporary glacier fluctuations in Nepal's khumbu himal using repeat photography. Himal. J. Sci. 2007, 4, 21-26. [CrossRef]

81. Schneider, E. The map of the" Khumbu Himal (Everest); Ergebnisse des Forshungsunternehmens Nepal Himalaya: Munich, German, 1967; Volume 1.

82. Schneider, E. Begleitworte zur Karte Khumbu Himal i und zur namensgebung. In Khumbu Himal; Springer: Heidelberg, Germany, 1967; pp. 430-446.

83. Yamada, T. Report for the First Research Expedition to Imja Glacier Lake; WECS Report No. 3/4/120892/1/1 Seq. No. 412; Snow and Glacier Hydrology; WECS: Kathmandu, Nepal, 1992.

84. Bolch, T.; Buchroithner, M.F.; Peters, J.; Baessler, M.; Bajracharya, S. Identification of glacier motion and potentially dangerous glacial lakes in the MT. Everest region/Nepal using spaceborne imagery. Nat. Hazards Earth Syst. Sci. 2008, 8, 1329-1340. [CrossRef]

85. Fujita, K.; Sakai, A.; Nuimura, T.; Yamaguchi, S.; Sharma, R.R. Recent changes in Imja Glacial Lake and its damming moraine in the Nepal Himalaya revealed by in situ surveys and multi-temporal aster imagery. Environ. Res. Lett. 2009, 4, 045205. [CrossRef]

86. Thakuri, S.; Salerno, F.; Bolch, T.; Guyennon, N.; Tartari, G. Factors controlling the accelerated expansion of Imja Lake, mount everest region, Nepal. Ann. Glaciol. 2016, 57, 245-257. [CrossRef]

87. Somos-Valenzuela, M.A.; McKinney, D.C.; Rounce, D.R.; Byers, A.C. Changes in Imja Tsho in the mount everest region of Nepal. Cryosphere 2014, 8, 1661-1671. [CrossRef]

88. Watanabe, T.; Ives, J.D.; Hammond, J.E. Rapid growth of a Glacial Lake in Khumbu Himal, Himalaya: Prospects for a catastrophic flood. Mt. Res. Dev. 1994, 14, 329-340. [CrossRef]

89. Sakai, A.; Chikita, K.; Yamada, T. Expansion of a moraine-dammed Glacial Lake, Tsho Rolpa, in Rolwaling Himal, Nepal Himalaya. Limnol. Oceanogr. 2000, 45, 1401-1408. [CrossRef]

90. Warren, C.R.; Glasser, N.F.; Harrison, S.; Winchester, V.; Kerr, A.R.; Rivera, A. Characteristics of tide-water calving at glaciar san rafael, chile. J. Glaciol. 1995, 41, 273-289. [CrossRef]

91. Haresign, E.; Warren, C.R. Melt rates at calving termini: A study at glaciar león, chilean patagonia. Geol. Soc. Lond. Spec. Publ. 2005, 242, 99-109. [CrossRef]

92. Benn, D.I.; Warren, C.R.; Mottram, R.H. Calving processes and the dynamics of calving glaciers. Earth-Sci. Rev. 2007, 82, 143-179. [CrossRef]

93. Wang, X.; Liu, S.; Ding, Y.; Guo, W.; Jiang, Z.; Lin, J.; Han, Y. An approach for estimating the breach probabilities of moraine-dammed lakes in the chinese himalayas using remote-sensing data. Nat. Hazards Earth Syst. Sci. 2012, 12, 3109-3122. [CrossRef]

94. Anacona, P.I.; Norton, K.P.; Mackintosh, A. Moraine-dammed lake failures in Patagonia and assessment of outburst susceptibility in the Baker Basin. Nat. Hazards Earth Syst. Sci. 2014, 14, 3243-3259. [CrossRef]

95. Wilson, R.; Glasser, N.F.; Reynolds, J.M.; Harrison, S.; Anacona, P.I.; Schaefer, M.; Shannon, S. Glacial lakes of the central and patagonian andes. Glob. Planet. Chang. 2018, 162, 275-291. [CrossRef]

96. Robson, B.A.; Nuth, C.; Nielsen, P.R.; Girod, L.; Hendrickx, M.; Dahl, S.O. Spatial variability in patterns of glacier change across the manaslu range, central Himalaya. Front. Earth Sci. 2018, 6, 12. [CrossRef]

97. Bishop, M.P.; Bush, A.B.G.; Furfaro, R.; Gillespie, A.R.; Hall, D.K.; Haritashya, U.K.; Shroder, J.F. Theoretical foundations of remote sensing for glacier assessment and mapping. In Global Land Ice Measurements from Space; Springer: Heidelberg, Germany, 2014; pp. 23-52.

98. Proy, C.; Tanre, D.; Deschamps, P.Y. Evaluation of topographic effects in remotely sensed data. Remote Sens. Environ. 1989, 30, 21-32. [CrossRef]

99. Reid, T.D.; Brock, B.W. Assessing ice-cliff backwasting and its contribution to total ablation of debris-covered Miage Glacier, Mont Blanc Massif, Italy. J. Glaciol. 2014, 60, 3-13. [CrossRef]

100. Immerzeel, W.W.; Kraaijenbrink, P.D.A.; Shea, J.M.; Shrestha, A.B.; Pellicciotti, F.; Bierkens, M.F.P.; De Jong, S.M. High-resolution monitoring of Himalayan glacier dynamics using unmanned aerial vehicles. Remote Sens. Environ. 2014, 150, 93-103. [CrossRef]

101. Steiner, J.F.; Pellicciotti, F.; Buri, P.; Miles, E.S.; Immerzeel, W.W.; Reid, T.D. Modelling ice-cliff backwasting on a debris-covered glacier in the Nepalese Himalaya. J. Glaciol. 2015, 61, 889-907. [CrossRef]

102. Buri, P.; Pellicciotti, F.; Steiner, J.F.; Miles, E.S.; Immerzeel, W.W. A grid-based model of backwasting of supraglacial ice cliffs on debris-covered glaciers. Ann. Glaciol. 2016, 57, 199-211. [CrossRef]

103. Miles, E.S.; Willis, I.C.; Arnold, N.S.; Steiner, J.; Pellicciotti, F. Spatial, seasonal and interannual variability of supraglacial ponds in the langtang valley of Nepal, 1999-2013. J. Glaciol. 2017, 63, 88-105. [CrossRef] 
104. Watson, C.S.; Quincey, D.J.; Smith, M.W.; Carrivick, J.L.; Rowan, A.V.; James, M.R. Quantifying ice cliff evolution with multi-temporal point clouds on the debris-covered Khumbu glacier, Nepal. J. Glaciol. 2017, 63, 823-837. [CrossRef]

105. Ohmura, A. Enhanced temperature variability in high-altitude climate change. Theor. Appl. Climatol. 2012, 110, 499-508. [CrossRef]

106. Rangwala, I.; Miller, J.R. Climate change in mountains: A review of elevation-dependent warming and its possible causes. Clim. Chang. 2012, 114, 527-547. [CrossRef]

107. Shea, J.M.; Immerzeel, W.W.; Wagnon, P.; Vincent, C.; Bajracharya, S. Modelling glacier change in the everest region, Nepal Himalaya. Cryosphere 2015, 9, 1105-1128. [CrossRef]

108. Lutz, A.F.; Immerzeel, W.W.; Shrestha, A.B.; Bierkens, M.F.P. Consistent increase in high asia's runoff due to increasing glacier melt and precipitation. Nat. Clim. Chang. 2014, 4, 587-592. [CrossRef]

109. Scherler, D.; Bookhagen, B.; Strecker, M.R. Spatially variable response of himalayan glaciers to climate change affected by debris cover. Nat. Geosci. 2011, 4, 156-159. [CrossRef]

110. Racoviteanu, A.E.; Arnaud, Y.; Baghuna, I.M.; Bajracharya, S.R.; Berthier, E.; Bhambri, R.; Bolch, T.; Byrne, M.; Chaujar, R.K.; Frauenfelder, R. Himalayan Glaciers (India, Bhutan, Nepal): Satellite observations of thinning and retreat. In Global Land Ice Measurements from Space; Springer: Heidelberg, Germany, 2014; pp. 549-582.

111. Brahmbhatt, R.M.; Rathore, B.P.; Pattnaik, S.; Jani, P.; Bahuguna, I.; Shah, R.D.; Rajawat, A.S. Peculiar characteristics of fragmentation of glaciers: A case study of western Himalaya, India. Int. J. Geosci. 2015, 6, 455-463. [CrossRef]

112. Sakai, A.; Fujita, K.; Yamada, T. Volume change of imja tsho in the Nepal Himalayas. In Proceedings of the ISDB 2003, Niigata, Japan, 7-10 December 2003; pp. 556-561.

113. GDH. G.L.O.F Risk Assessment on the Thulagi Lake, Nepal; GDH: Saint-Pancrasse, France, 2013 ; p. 81.

114. Quincey, D.J.; Luckman, A.; Benn, D. Quantification of everest region glacier velocities between 1992 and 2002, using satellite radar interferometry and feature tracking. J. Glaciol. 2009, 55, 596-606. [CrossRef]

115. Quincey, D.J.; Richardson, S.D.; Luckman, A.; Lucas, R.M.; Reynolds, J.M.; Hambrey, M.J.; Glasser, N.F. Early recognition of glacial lake hazards in the Himalaya using remote sensing datasets. Glob. Planet. Chang. 2007, 56, 137-152. [CrossRef]

116. Finkel, R.C.; Owen, L.A.; Barnard, P.L.; Caffee, M.W. Beryllium-10 dating of mount everest moraines indicates a strong monsoon influence and glacial synchroneity throughout the Himalaya. Geology 2003, 31, 561-564. [CrossRef]

117. Owen, L.A.; Robinson, R.; Benn, D.I.; Finkel, R.C.; Davis, N.K.; Yi, C.; Putkonen, J.; Li, D.; Murray, A.S. Quaternary glaciation of mount everest. Q. Sci. Rev. 2009, 28, 1412-1433. [CrossRef]

118. Kulkarni, A.V.; Rathore, B.P.; Mahajan, S.; Mathur, P. Alarming retreat of Parbati Glacier, Beas Basin, Himachal Pradesh. Curr. Sci. 2005, 1844-1850.

119. Jiskoot, H.; Curran, C.J.; Tessler, D.L.; Shenton, L.R. Changes in clemenceau icefield and chaba group Glaciers, Canada, related to hypsometry, tributary detachment, length-slope and area-aspect relations. Ann. Glaciol. 2009, 50, 133-143. [CrossRef]

120. Haritashya, U.K.; Bishop, M.P.; Shroder, J.F.; Bush, A.B.G.; Bulley, H.N.N. Space-based assessment of glacier fluctuations in the wakhan pamir, afghanistan. Clim. Chang. 2009, 94, 5-18. [CrossRef]

121. Bolch, T.; Pieczonka, T.; Benn, D.I. Multi-decadal mass loss of glaciers in the everest area (Nepal Himalaya) derived from stereo imagery. Cryosphere 2011, 5, 349-358. [CrossRef]

122. Jones, D.B.; Harrison, S.; Anderson, K.; Selley, H.L.; Wood, J.L.; Betts, R.A. The distribution and hydrological significance of rock glaciers in the Nepalese Himalaya. Glob. Planet. Chang. 2018, 160, 123-142. [CrossRef]

123. Nicholson, L.; Benn, D.I. Calculating ice melt beneath a debris layer using meteorological data. J. Glaciol. 2006, 52, 463-470. [CrossRef]

124. Reid, T.D.; Brock, B.W. An energy-balance model for debris-covered glaciers including heat conduction through the debris layer. J. Glaciol. 2010, 56, 903-916. [CrossRef]

125. Sakai, A.; Takeuchi, N.; Fujita, K.; Nakawo, M. Role of supraglacial ponds in the ablation process of a debris-covered glacier in the Nepal Himalayas. In Debris-Covered Glaciers; International Association of Hydrological Sciences: Oxford, UK, 2000; pp. 119-132.

126. Mertes, J.R.; Thompson, S.S.; Booth, A.D.; Gulley, J.D.; Benn, D.I. A conceptual model of supra-glacial lake formation on debris-covered glaciers based on GPR facies analysis. Earth Surf. Process. Landf. 2017, 42, 903-914. [CrossRef] 
127. Westoby, M.J.; Glasser, N.F.; Brasington, J.; Hambrey, M.J.; Quincey, D.J.; Reynolds, J.M. Modelling outburst floods from moraine-dammed glacial lakes. Earth-Sci. Rev. 2014, 134, 137-159. [CrossRef]

128. Emmer, A. Geomorphologically effective floods from moraine-dammed lakes in the cordillera Blanca, Peru. Q. Sci. Rev. 2017, 177, 220-234. [CrossRef]

129. Rounce, D.R.; Byers, A.C.; Byers, E.A.; McKinney, D.C. Brief communication: Observations of a glacier outburst flood from Lhotse Glacier, Everest area, Nepal. Cryosphere 2017, 11, 443-449. [CrossRef]

130. GlacierHub. A Visit to the Source of a Recent Glacier Flood in Nepal. Available online: http://glacierhub. org/2017/05/17/a-visit-to-the-source-of-a-recent-glacier-flood-in-nepal/ (accessed on 5 April 2018).

131. Shangguan, D.; Ding, Y.; Liu, S.; Xie, Z.; Pieczonka, T.; Xu, J.; Moldobekov, B. Quick release of internal water storage in a glacier leads to underestimation of the hazard potential of glacial lake outburst floods from lake merzbacher in central tian shan mountains. Geophys. Res. Lett. 2017, 44, 9786-9795. [CrossRef]

132. Byers, A.C.; Byers, E.A.; McKinney, D.C.; Rounce, D.R. A field-based study of impacts of the 2015 earthquake on potentially dangerous Glacial Lakes in Nepal. HIMALAYA J. Assoc. Nepal Himal. Stud. 2017, $37,7$.

133. Kargel, J.S.; Leonard, G.J.; Shugar, D.H.; Haritashya, U.K.; Bevington, A.; Fielding, E.J.; Fujita, K.; Geertsema, M.; Miles, E.S.; Steiner, J. Geomorphic and geologic controls of geohazards induced by Nepal's 2015 Gorkha earthquake. Science 2016, 351, aac8353. [CrossRef] [PubMed]

134. Xu, J.; Grumbine, R.E.; Shrestha, A.; Eriksson, M.; Yang, X.; Wang, Y.U.N.; Wilkes, A. The melting himalayas: Cascading effects of climate change on water, biodiversity, and livelihoods. Conserv. Biol. 2009, 23, 520-530. [CrossRef] [PubMed]

135. Fattet, M.; Fu, Y.; Ghestem, M.; Ma, W.; Foulonneau, M.; Nespoulous, J.; Le Bissonnais, Y.; Stokes, A. Effects of vegetation type on soil resistance to erosion: Relationship between aggregate stability and shear strength. CATENA 2011, 87, 60-69. [CrossRef]

136. Carey, M.; Huggel, C.; Bury, J.; Portocarrero, C.; Haeberli, W. An integrated socio-environmental framework for glacier hazard management and climate change adaptation: Lessons from lake 513, cordillera blanca, Peru. Clim. Chang. 2012, 112, 733-767. [CrossRef]

(C) 2018 by the authors. Licensee MDPI, Basel, Switzerland. This article is an open access article distributed under the terms and conditions of the Creative Commons Attribution (CC BY) license (http:/ / creativecommons.org/licenses/by/4.0/). 